\title{
Promoter hypermethylation of the SFRP2 gene is a high-frequent alteration and tumor-specific epigenetic marker in human breast
}

\section{cancer}

\author{
Jürgen Veeck ${ }^{1}$, Erik Noetzel ${ }^{1}$, Nuran Bektas ${ }^{1}$, Edgar Jost ${ }^{2}$, Arndt Hartmann ${ }^{3}$, \\ Ruth Knüchel ${ }^{1}$ and Edgar Dahl*1
}

\begin{abstract}
Address: ${ }^{1}$ Molecular Oncology Group, Institute of Pathology, University Hospital of the RWTH Aachen, Pauwelsstrasse 30, 52074 Aachen Germany, ${ }^{2}$ Department of Internal Medicine IV (Hematology and Oncology), University Hospital of the RWTH Aachen, Pauwelsstrasse 30, 52074 Aachen, Germany and ${ }^{3}$ Department of Pathology, University of Erlangen, Krankenhausstrasse 12, 91054 Erlangen, Germany

Email: Jürgen Veeck - juergen.veeck@rwth-aachen.de; Erik Noetzel - enoetzel@ukaachen.de; Nuran Bektas - nbektas@ukaachen.de; Edgar Jost - ejost@ukaachen.de; Arndt Hartmann - arndt.hartmann@uk-erlangen.de; Ruth Knüchel - rknuechel-clarke@ukaachen.de; Edgar Dahl* - edahl@ukaachen.de

* Corresponding author
\end{abstract}

Published: 6 November 2008

Molecular Cancer 2008, 7:83 doi:10.1 186/1476-4598-7-83
Received: 10 May 2008

Accepted: 6 November 2008

This article is available from: http://www.molecular-cancer.com/content/7/I/83

(C) 2008 Veeck et al; licensee BioMed Central Ltd.

This is an Open Access article distributed under the terms of the Creative Commons Attribution License (http://creativecommons.org/licenses/by/2.0), which permits unrestricted use, distribution, and reproduction in any medium, provided the original work is properly cited.

\begin{abstract}
Background: We have previously reported that expression of the Wnt antagonist genes SFRPI and SFRP5 is frequently silenced by promoter hypermethylation in breast cancer. SFRP2 is a further Wnt inhibitor whose expression was recently found being downregulated in various malignancies. Here we investigated whether SFRP2 is also implicated in human breast cancer, and if so whether SFRP2 promoter methylation might serve as a potential tumor biomarker.
\end{abstract}

Methods: We analyzed SFRP2 mRNA expression and SFRP2 promoter methylation in 10 breast cell lines, 199 primary breast carcinomas, 20 matched normal breast tissues and 17 cancer-unrelated normal breast tissues using RT-PCR, realtime PCR, methylation-specific PCR and Pyrosequencing, respectively. SFRP2 protein expression was assessed by immunohistochemistry on a tissue microarray. Proliferation assays after transfection with an SFRP2 expression vector were performed with mammary MCFIOA cells. Statistical evaluations were accomplished with SPSS I4.0 software.

Results: Of the cancerous breast cell lines, 7/8 (88\%) lacked SFRP2 mRNA expression due to SFRP2 promoter methylation $(P<0.00 I)$. SFRP2 expression was substantially restored in most breast cell lines after treatment with 5 -aza2'-deoxycytidine and trichostatin A. In primary breast carcinomas SFRP2 protein expression was strongly reduced in 93 of I 25 specimens (74\%). SFRP2 promoter methylation was detected in $165 / 199$ primary carcinomas (83\%) whereas all cancer-related and unrelated normal breast tissues were not affected by SFRP2 methylation. SFRP2 methylation was not associated with clinicopathological factors or clinical patient outcome. However, loss of SFRP2 protein expression showed a weak association with unfavorable patient overall survival $(P=0.07 \mathrm{I})$. Forced expression of SFRP2 in mammary MCFIOA cells substantially inhibited proliferation rates $(P=0.045)$.

Conclusion: The SFRP2 gene is a high-frequent target of epigenetic inactivation in human breast cancer. Its methylation leads to abrogation of SFRP2 expression, conferring a growth advantage to epithelial mammary cells. This altogether supports a tumor suppressive function of SFRP2. Although clinical patient outcome was not associated with SFRP2 methylation, the high frequency of this epimutation and its putative specificity to neoplastic cells may qualify SFRP2 promoter methylation as a potential candidate screening marker helping to improve early breast cancer detection. 


\section{Background}

Aberrant promoter methylation leading to functional inactivation of tumor suppressor genes is a well recognized mechanism capable of driving carcinogenesis $[1,2]$. In human breast cancer numerous genes have been identified with abolished expression due to 5'-cytosine methylation within their gene promoter (recently reviewed in [3]). Typically those genes affect important aspects of normal growth control, like cell cycle regulation (p16 INK4a) [4], steroid receptor biology (estrogen receptor- $\alpha$ ) [5], cell adhesion (E-cadherin) [6], apoptosis (death-associated protein (DAP) kinase-1) [7] or extracellular matrix integrity (ITIH5) [8], all of which confers, in case of expression loss, growth advantages to neoplastic cells. Importantly, the observation that DNA methylation of the same gene may occur both in premalignant lesions, such as atypical hyperplasia of the breast, and in carcinoma [9] suggests that DNA methylation might serve as ideal biomarker for early cancer detection or patient risk assessment in clinical oncology [10]. Thus, identification and validation of epigenetically silenced cancer-related genes is of critical importance in the search of novel tumor biomarkers.

Secreted frizzled-related proteins (SFRPs) constitute a family of extracellular Wnt signaling antagonists, of which five members (SFRP1-5) have been identified to date [11]. SFRPs sequester Wnt molecules at the cell surface membrane [12] and by this are recognized as sensitive regulators of the canonical Wnt signaling pathway [13]. Aberrant activation of Wnt signaling has been associated with the pathogenesis of virtually all human cancers (reviewed in [14]). In breast tumor tissues, activated Wnt signaling has been repeatedly observed as determined by nuclear and cytoplasmic accumulation of $\beta$-catenin [15$18]$, arguing for a disrupted equilibrium between Wnt and SFRP expression in this tumor type. In line with this, previous studies have shown that expression of SFRP genes is commonly silenced by promoter methylation in human cancers [19-26]. In breast cancer, SFRP1 and SFRP5 have been identified as targets of aberrant epigenetic inactivation to date, and either promoter methylation was found to be associated with unfavorable patient prognosis $[27,28]$. SFRP2 has been previously identified as epigenetic target in other tumor entities, such as colon [29], oesophagus [30], bladder [31], stomach [23,24], liver [25] and lung cancer [32]. Interestingly, in all tumor entities SFRP2 methylation was detected with a high frequency of $>50 \%$ of cancer patients, ranging from $52 \%$ in lung cancer to $96 \%$ in gastric cancer, which suggests that SFRP2 methylation might potentially be useful as a ubiquitous pan-tumor marker in cancerous tissues, and possibly also in body fluids. Consequently, Urakami et al. [22] demonstrated that of all investigated SFRPs only SFRP2 methylation proved to be a valuable independent prediction factor for bladder cancer in urine samples. At the same time, SFRP2 methylation was found to occur high-frequent in colon cancer $(83-90 \%)[33,19]$, which may have forced the establishment of SFRP2 methylation as a promising sensitive screening marker for the stool-based detection of colorectal cancer and premalignant lesions [3436].

Very recently, Suzuki et al. [37] reported about SFRP2 methylation in human breast cancer, and their study demonstrated an inhibitory effect of SFRP2 on canonical Wnt signaling in breast cancer cell lines. However, SFRP2 expression analyses in normal and breast carcinoma tissues as well as patient survival analysis in relation to SFRP2 methylation were not addressed. Our approach was to investigate SFRP2 expression and promoter methylation in breast cell lines, primary breast carcinomas and normal breast tissues, followed by comprehensive statistical correlation analysis with clinicopathological factors and patient survival. We also investigated a functional role of SFRP2 in a breast cell line with regard to growth behaviour. In summary, our data confirm that the SFRP2 gene is high-frequently inactivated by promoter methylation in human breast cancer and that loss of SFRP2 expression confers a growth advantage to mammary epithelial cells. In addition, we provide evidence that SFRP2 protein expression is commonly reduced in breast cancer and that SFRP2 methylation might be a potential biomarker useful for early detection of this disease.

\section{Methods}

\section{Cryoconserved clinical materials}

According to a multi-center study design, 20 matched tumor/macroscopically normal samples of breast cancer patients (median patient age: 67 years; range $48-86$ years) and 179 unmatched breast carcinomas (median patient age: 57 years; range 28-96 years) were obtained from patients treated by primary surgery for breast cancer at the Departments of Gynecology at the University Hospitals of Aachen, Jena, Regensburg and Düsseldorf, Germany. None of the patients had received neo-adjuvant chemotherapy. Inclusion criterion for ipsilateral normal breast tissue was a distance of $>2 \mathrm{~cm}$ to the carcinoma margin. All patients gave informed consent for retention and analysis of their tissue for research purposes and the Institutional Review Boards of the participating centers approved the study. The selection of cases was based on availability of tissue. Cases were not stratified for any known preoperative or pathological prognostic factor. Tumor histology was determined according to the criteria of the WHO (2003), while disease stage was assessed according to UICC [38]. Tumors were graded according to Bloom and Richardson, as modified by Elston and Ellis [39]. Hormone receptor positivity was defined as an immunoreactivity score (IRS) $\geq 3$ [40]. For 136 patients follow-up data were available with a median time of 64 months (range 1- 
174 months). Tumor material was immediately snap-frozen in liquid nitrogen after surgery. Hematoxylin/Eosinstained sections were prepared for assessing the percentage of tumor cells; only samples with greater than $70 \%$ tumor cells were selected for analysis. Samples were dissolved in lysis buffer followed by DNA isolation using the QIAamp DNA Mini Kit (Qiagen, Hilden, Germany) according to the manufacturer's recommendations. For patient characteristics see additional file 1 .

\section{Formalin-fixed, paraffin-embedded (FFPE) clinical material}

A total of 17 archival FFPE normal breast tissues were obtained from the Institute of Pathology, University Hospital of the RWTH Aachen, Germany. These patients had undergone breast reduction surgery without the condition of cancer. The median age in the cancer-unrelated normal breast tissue set was 33 years (range 22-61 years). Per sample, five consecutive sections (each $10 \mu \mathrm{m}$ ) were deparaffinized and rehydrated in a decreasing alcohol series prior to DNA extraction by use of the QIAamp DNA Mini Kit.

SFRP2 protein expression was assessed using a tissue microarray (TMA) consisting of 125 breast carcinomas, four ductal carcinomas in situ (DCIS) and 10 normal breast tissues that have been described previously [41]. The TMA contained one tissue core from non-selected, FFPE primary breast carcinoma specimens diagnosed between 1994 and 2002 at the Institute of Pathology, University of Regensburg, Germany. Histological, all tumors were graded according to Bloom and Richardson, as modified by Elston and Ellis [39]. Clinical follow-up data were available for 124 breast cancer patients with a median follow-up period of 80 months (range 5-114 months). All patients gave informed consent for retention and analysis of their tissue for research purposes and the Institutional Review Board of the participating centers approved the study.

\section{Immunohistochemistry}

The TMA was subjected to immunostaining using the K5007 Kit (DAKO, Hamburg, Germany) following the manufacturer's instructions. Antigen retrieval was performed by pretreatment in citrate buffer $(\mathrm{pH} 7)$ in a microwave oven (20 min, $200 \mathrm{~W})$. Samples were incubated for 30 min with the primary SFRP2 antibody (rabbit polyclonal IgG; H-140; 1:75; Santa Cruz Biotechnology, Santa Cruz, CA), washed, and incubated for $10 \mathrm{~min}$ with the secondary antibody (biotinylated polylink; DAKO). Diaminobenzidin (DAKO) was used for antibody detection. In negative controls the primary antibody was omitted. An experienced breast cancer pathologist (N.B.) scored the immunohistochemical staining according to the scoring system suggested by Remmele and Stegner
[40]. Feasibility of the antibody for immunohistochemical analysis of breast tissue has been previously demonstrated e.g. by Lee et al. [42].

\section{Cell lines}

The benign cell lines HMEC and MCF10A as well as the cancerous breast cell lines BT20, BT474, Hs578T, MCF7, MDA-MB-231, MDA-MB-453, SKBR3, T47D and ZR75-1 were obtained from the American Type Culture Collection (Rockville, MA) and cultured as recommended by the vendor.

\section{Reverse transcription (RT-) PCR and semi-quantitative realtime PCR}

RNA isolation, RT-PCR and SYBR Green I realtime PCR (Roche Diagnostics, Mannheim, Germany) were performed as described elsewhere [27]. Quality of cDNA was checked after each preparation by standard RT-PCR using glyceraldehyde-3-phosphate-dehydrogenase (GAPDH) primers that yield an amplification product of $510 \mathrm{bp}$. To ensure experiment accuracy, all quantitative measurements were performed in triplicate. Intron-spanning primer sequences and cycle conditions are given in additional file 2 .

\section{Sodium bisulfite-modification and methylation-specific PCR (MSP)}

Of the genomic DNA, $1 \mu \mathrm{g}$ was bisulfite-modified using the EZ DNA Methylation Kit (Zymo Research, Orange, CA) according to the manufacturer's recommendations. The final precipitate was eluted in $20 \mu \mathrm{l}$ TRIS buffer (10 $\mathrm{mM}$ ). For MSP, one $\mu \mathrm{l}$ of modified DNA was amplified using MSP primers (see additional file 2) that specifically recognized either the unmethylated or methylated gene promoter sequence after bisulfite-conversion. Each primer pair mapped to nine cytosine-phosphate-guanine dinucleotide $(\mathrm{CpG})$ sites in order to specifically discriminate between methylated and non-methylated DNA. Further 11 non-CpG cytosines within the primer pair specific for methylated DNA and 13 non-CpG cytosines within the primer pair specific for non-methylated DNA guaranteed unequivocal amplification of bisulfite-converted DNA. Primers defined an amplicon between +19 and +163 relative to the transcription start site $(+1)$ of the SFRP2 gene. Reaction volumes of $25 \mu$ contained $1 \times$ MSP-buffer [44], $400 \mathrm{nM}$ each of methylation and nonmethylation-specific primers, respectively, and $1.25 \mathrm{mM}$ of dNTPs. One drop of mineral oil was added to the reaction tube. The PCR was initiated as "Hot Start" PCR at $94^{\circ} \mathrm{C}$ and held at $80^{\circ} \mathrm{C}$ before the addition of 1.25 units Taq DNA polymerase (Promega, Madison, WI). Cycle conditions were: $95^{\circ} \mathrm{C}$ for $5 \mathrm{~min}, 35$ cycles of $95^{\circ} \mathrm{C}$ for 30 $\mathrm{s}, 60^{\circ} \mathrm{C}$ for $30 \mathrm{~s}, 72^{\circ} \mathrm{C}$ for $40 \mathrm{~s}$ and a final extension at $72^{\circ} \mathrm{C}$ for $5 \mathrm{~min}$. Blood lymphocyte DNA from a healthy donor was bisulfite-modified to serve as a control for the 
unmethylated promoter sequence [45], DNA from the cancerous breast cell line BT20 served as control for methylated alleles. Amplification products were visualized on $3 \%$ low range ultra agarose gel (Bio-Rad Laboratories, Hercules, CA) containing ethidium bromide and illuminated under ultraviolet (UV) light.

\section{Pyrosequencing}

Quantitative Pyrosequencing of a SFRP2 promoter fragment was performed by use of a Pyromark ID device, PyroGoldSQA Reagent Kit and Pyro Q-CpG software (Biotage, Uppsala, Sweden). Initially, a 291 bp fragment of the SFRP2 promoter (relative position -28 to +263 ), covering the hybridization sites for MSP primers, was amplified with degenerate primers irrespective of the methylation status, which assures unbiased DNA amplification. To enable single strand preparation the reverse primer was 5'-biotinylated. Reaction volumes of $50 \mu \mathrm{l}$ contained $1 \times$ GoTaq buffer, 2.5 units GoTaq polymerase (Promega), $2.5 \mathrm{mM}$ of $\mathrm{MgCl}_{2}, 400 \mathrm{nM}$ of primers, $500 \mathrm{nM}$ of each dNTP, and $3 \mu$ lof bisulfite-converted DNA as template. Reactions were initiated as "Hot Start" PCR at $95^{\circ} \mathrm{C}$ for $3 \mathrm{~min}$ and held at $80^{\circ} \mathrm{C}$ before addition of $\mathrm{Taq}$ polymerase. Cycle conditions were: $94^{\circ} \mathrm{C}$ for $3 \mathrm{~min}, 50$ cycles of $94^{\circ} \mathrm{C}$ for $15 \mathrm{sec}, 58^{\circ} \mathrm{C}$ for $30 \mathrm{sec}, 72^{\circ} \mathrm{C}$ for $30 \mathrm{sec}$, and a final extension step at $72^{\circ} \mathrm{C}$ for $5 \mathrm{~min}$. PCR was carried out in a PTC-200 cycler (Bio-Rad, formerly MJ Research, Hercules, CA). Prior to sequencing, aliquots of the amplificate were analyzed on a $2 \%$ agarose gel containing ethidium bromide under UV light. Single strand separation of the remaining amplificate $(40 \mu \mathrm{l})$ was performed with a PyroMark Vacuum Prep Workstation (Biotage). Amplificate was immobilized to StreptavidinSepharose HP beads (Amersham Biosciences, Uppsala, Sweden), washed, denatured and the biotinylated strands were released into $40 \mu \mathrm{l}$ of annealing buffer containing $400 \mathrm{nM}$ of forward sequencing primer. Sequencing started with position +3 (relative to the TSS) and was continued to position +167 , covering a total of 22 sequential CpG sites. The following sequence represents the SFRP2 promoter sequence that was analyzed by pyrosequencing: AYGGTTTATTTTGTTTTTTYGGGTYGGAGT TTTTYGGAG TTGYGYGYGGGTT TGTAGTGTTTYGTTYGYGTTGTTTTTTYGGTGTTTYGTTTTTTYGYGTT TTAGTYGTYGGTTGTT AGTTTTTYGGGGTTTYGAGTYGTATTTAGYGAAGAGAGY GGGTTYGG.

Universal bisulfite-converted polymethylated and unmethylated DNA (Epi Tect Control DNA Set; Qiagen, Hilden, Germany) served as technical controls for SFRP2 methylation and non-methylation, respectively. Pyrosequencing primers are available on request.

\section{5-aza-2'-deoxycytidine (DAC) and trichostatin A (TSA) treatment}

We plated cells at $3 \times 10^{4}$ cells $/ \mathrm{cm}^{2}$ in a six-well plate on day 0 . The demethylating agent DAC (Sigma-Aldrich, Deisenheim, Germany) was added to a final concentration of $1 \mu \mathrm{M}$ in fresh medium on days 1, 2 and 3. Additionally, $300 \mathrm{nM}$ TSA (Sigma-Aldrich) was added on day 3. Cells were harvested on day 4 for RNA and DNA extraction. Control cells were incubated without the addition of DAC or TSA and fresh medium was also supplied on days 1,2 and 3 .

\section{Transient transfection}

Cells were seeded at a density of $3 \times 10^{4}$ cells $/ \mathrm{cm}^{2}$ and transfected 24 hours after incubation with $100 \mathrm{ng} / \mathrm{cm}^{2}$ of plasmid DNA in the following manner: $100 \mathrm{ng}$ of empty pCMV-hemagglutinin (HA) vector control (Clontech, Heidelberg, Germany), or 50 ng of pCMV-HA + 50 ng pCMV-HA/SFRP2, or 50 ng of pCMV-HA + 50 ng pcDNA3.1-HisA/WNT1, or 50 ng pCMV-HA/SFRP2 + 50 ng pcDNA3.1-HisA/WNT1 [19] applying the FuGENE 6 transfection system (Roche Diagnostics) and a 3:1 transfection ratio according to the manufacturer's instructions.

\section{Proliferation assays}

MCF10A cells were transfected in 96-well plates as described above and an XTT-proliferation assay (Roche Diagnostics) was performed on day 0, 1, 2 and 3 after transfection by determining the optical density of the supernatants at $480 \mathrm{~nm}$ minus the optical density of the supernatants at $690 \mathrm{~nm}$. To enhance experimental accuracy, six replicas were seeded. For the colony formation assay cells were transfected accordingly in six-well plates and kept for three weeks under selective force of the antibiotic G418 (700 $\mu \mathrm{g} / \mathrm{ml}$ ) (Invitrogen, Carlsbad, CA). After incubation, colonies were washed with phosphate-buffered saline, fixed and stained for 30 minutes $(0.25 \%$ crystal violet in $10 \%$ formalin/ $80 \%$ methanol), washed three times with distilled water and photographed.

\section{Statistical methods}

Statistical analyses were completed using the software package SPSS, version 14.0 (SPSS Inc., Chicago, IL). Differences were considered significant when $P$-values were below 0.05. A two-sided non-parametric Mann-Whitney U-test and a paired student's t-test were performed to analyze differences in expression levels. Associations between metrical variables were determined by a linear regression analysis. To study statistical associations between clinicopathological factors and SFRP2 expression or SFRP2 promoter methylation status contingency-tables and twosided Fisher's exact tests were accomplished. Survival curves were calculated using the Kaplan-Meier method, with significance evaluated by two-sided log-rank statis- 
tics. Overall survival (OS) ( $\mathrm{n}=136$ for MSP samples) was measured from the day of surgery until tumor-related death $(20.6 \%, \mathrm{n}=28)$ and was censored for patients alive at last contact $(69.1 \%, \mathrm{n}=94)$, in case of death unrelated to the tumor $(3.7 \%, \mathrm{n}=5)$ or when the death cause was unknown $(6.6 \%, \mathrm{n}=9)$. Disease-free survival (DFS) $(\mathrm{n}=$ 136 for MSP samples) was measured from surgery until local or distant relapse $(36.8 \%, \mathrm{n}=50)$ and censored for patients alive without evidence of relapse at the last follow-up $(63.2 \%, \mathrm{n}=86)$.

\section{Results}

Expression of SFRP2 mRNA is reduced in breast cancer cell lines

Initiating our analysis, we used the RT-PCR technique to evaluate whether SFRP2 mRNA is differentially expressed in human breast cell lines. SFRP2 mRNA expression was detectable in the benign cell line HMEC, whilst its expression was absent in the cancerous cell lines MDA-MB-231, MCF7, SKBR3, T47D, MDA-MB-453, BT20 and BT474 (Figure 1A). Of the cancerous cell lines only Hs578T exhibited strong SFRP2 expression. However, SFRP2 expression was also absent in the benign cell line MCF10A. Additionally, in a commercially available cDNA of human normal breast tissue (Clontech, Heidelberg, Germany) SFRP2 was strongly expressed while its expression was substantially reduced in Clontech's cDNA of primary breast carcinoma.

\section{Methylation of the SFRP2 promoter in breast cancer cell lines}

Analysis of the SFRP2 gene promoter on chromosome 4q31 [46] using the genomic DNA information contained in Ensembl contig ENSG00000145423 [47] revealed a CpG island (CGI) between base position -818 to +743 relative to the expected transcription start site $(+1)$, according to the CGI definition of Takai and Jones [48]. Further exploration of this CGI using Methprimer software [49] identified three regions of particularly high CpG density (399 to $-151,-6$ to +332 , and +486 to +685 ) (Figure $1 \mathrm{~B}$ ). Since sequence integrity of the first SFRP2 exon was demonstrated to be most essential for efficient RNA transcription in a luciferase promoter assay [24] we chose the central CGI (-6 to +332) for subsequent methylation analysis by application of the highly specific MSP primers described by Suzuki et al. [29] and others [24,37]. First, we assessed SFRP2 promoter methylation in eight cancerous and two non-cancerous cell lines. Six of the analyzed cell lines (MCF10A, MDA-MB-231, MCF7, MDA-MB-453, BT20 and BT474) exhibited a methylated SFRP2 promoter sequence in the analyzed region (Figure 1C). Two cell lines (SKBR3 and T47D) showed partial promoter methylation, since a mixture of unmethylated and methylated DNA sequence could be detected in the same sample. One malignant cell line (Hs578T) and benign HMEC cells revealed solely unmethylated SFRP2 promoter sequence. This result correlates with the above described finding that Hs578T and HMEC cells exhibited strong SFRP2 mRNA expression whereas in all cell lines with aberrant methylation SFRP2 mRNA expression was absent. Interestingly, SFRP2 mRNA was not expressed at detectable levels from unmethyated alleles in SKBR3 and T47D, which may be due to repressing mechanisms that are codominant to the effect of promoter methylation in these cells.

\section{Re-expression of SFRP2 mRNA after in vitro DNA demethylation}

We next asked whether SFRP2 promoter methylation is functionally associated with loss of SFRP2 mRNA expression in breast cell lines. To address this question we treated four representative breast cancer cell lines for four days with $1 \mu \mathrm{M}$ of the methyltransferase inhibitor DAC and one day with $300 \mathrm{nM}$ of the histone deacetylase inhibitor TSA. As seen in Figure 2A, in three cell lines (BT20, MCF7 and T47D) the DAC/TSA treatment resulted in a clear increase of unmethylated SFRP2 promoter sequence, only in SKBR3 cells there was no visible difference detectable. Interestingly, BT20 and MCF7 showed demethylation after the addition of DAC alone, whereas in T47D cells such effect was only achieved by the combination of DAC and TSA. Before the treatment, none of the cell lines showed detectable SFRP2 mRNA expression (Figure 2B). The treatment with $1 \mu \mathrm{M}$ DAC alone did not reverse SFRP2 gene repression in these cells. TSA, in contrast, was able to induce some SFRP2 expression in SKBR3 and T47D cells. Importantly, only the combination of both drugs substantially restored SFRP2 mRNA expression in all analyzed cell lines.

To further prove that the demethylating treatment did not result in unspecific upregulation of gene expression, we determined the expression of the growth promoting gene cyclin D1, which is a direct read-out gene of active Wnt signaling [50] and whose expression is commonly elevated in breast cancer [51]. Using realtime PCR we observed that cyclin D1 mRNA expression was significantly reduced ( $P=0.029$, two-tailed Mann-Whitney Utest) after the demethylation treatment (43-fold in BT20, 14-fold in SKBR3, 8-fold in T47D and 6-fold in MCF7, Figure 2C), suggesting that inhibitors of proliferation, such as SFRPs which are downregulated in breast cancer cell lines, have been reactivated and were able to block Wnt signaling in these cells.

\section{Methylation of the SFRP2 promoter in primary breast carcinoma and normal breast tissue}

In order to answer the question whether SFRP2 promoter methylation occurs in primary breast carcinoma as well we analyzed 199 mammary tumor samples by MSP. For 20 breast tumors corresponding tissues of histological 

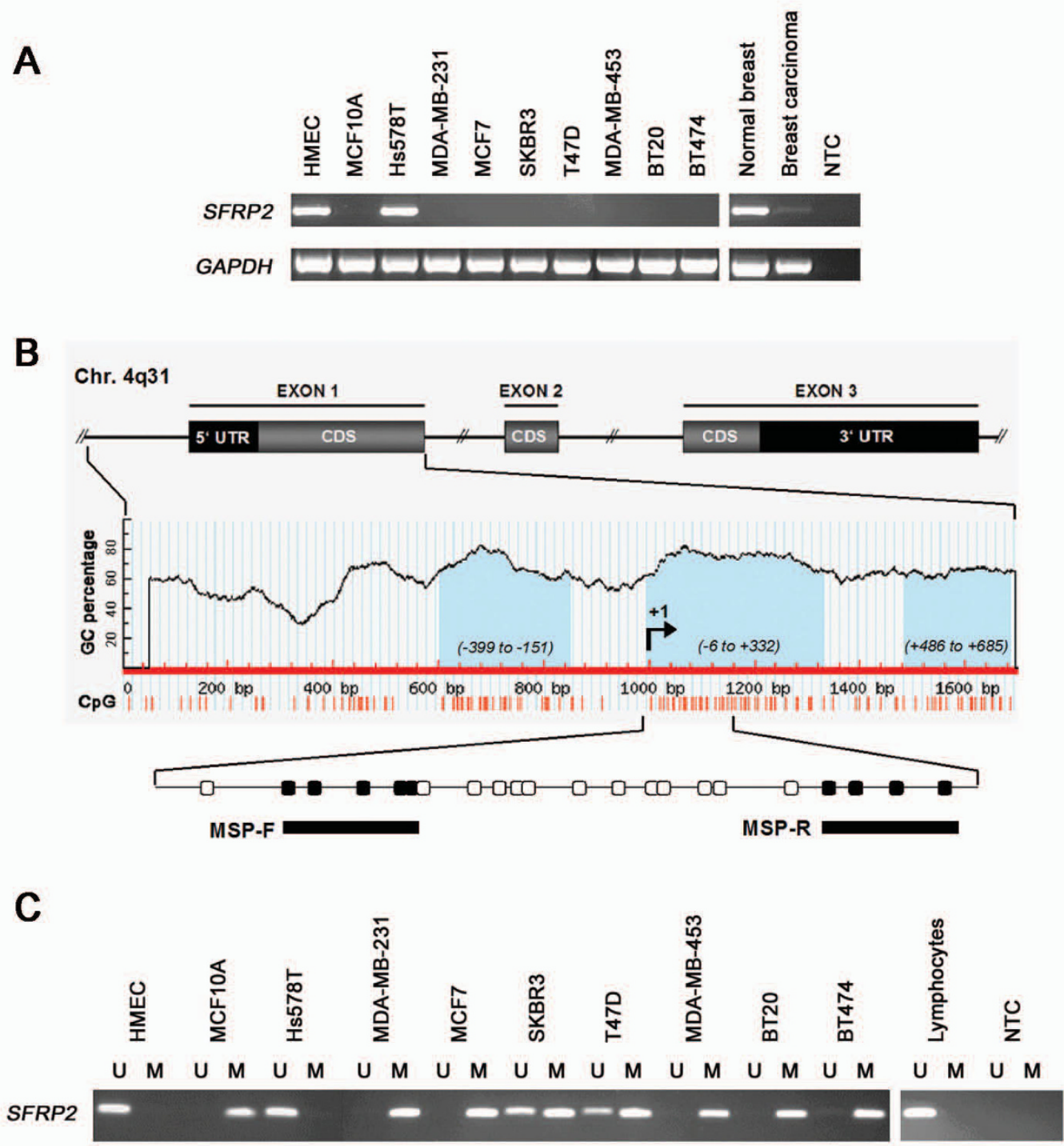

\section{Figure I}

SFRP2 expression and promoter methylation in breast cancer cell lines. (A) SFRP2 mRNA expression in benign and malignant cell lines was determined by RT-PCR. All but one malignant cell line (Hs578T) completely lacked SFRP2 mRNA expression. Of the two benign breast cell lines (MCFIOA and HMEC) only HMEC cells were found to express abundant SFRP2 mRNA. In a commercially available human normal breast tissue cDNA SFRP2 expression was clearly detectable, while expression was strongly reduced in a corresponding cDNA of human malignant breast tissue. (B) Genomic structure of the human SFRP2 gene on chromosome 4q3I. Bioinformatic analysis revealed three CGls (light blue), located within the SFRP2 promoter (left CGI), the 5' untranslated region (UTR; central CGI) and the coding sequence (CDS; right CGI). Methylation of the central CGI was explored by MSP. Circles indicate CPG sites; filled circles represent MSP forward (MSP-F) and reverse (MSP-R) primer hybridization sites. Indicated positions are related to the transcription start site $(+I)$ initiating the 5'-UTR. (C) MSP was performed with bisulfite-treated DNA from the same breast cell lines as in A. DNA bands in lanes labeled with $U$ indicate PCR products amplified with primers recognizing unmethylated SFRP2 promoter sequence. DNA bands in lanes labeled with M represent amplification products with methylation-specific primers. Five out of eight mammary tumor cell lines exhibit complete promoter methylation (MDA-MB-23I, MCF7, MDA-MB-453, BT20 and BT474), two cell lines show partial SFRP2 methylation (SKBR3 and T47D). In Hs578T, only unmethylated SFRP2 promoter sequence could be detected, like it was also found in benign HMEC cells. In addition, lymphocyte DNA from a healthy donor did not reveal SFRP2 methylation. GAPDH served as cDNA loading control; NTC represents the no template control. 
normal breast epithelium were available and analyzed in parallel. Representative results are shown in Figure 3. In total, 165 of 199 tumor samples (83\%) showed SFRP2 promoter methylation as a PCR product could be amplified with methylation-specific primers (e.g. \#103 in Figure $3)$, and 34 of 199 tumors (17\%) showed no evidence of promoter methylation since exclusive amplification signals were obtained with primers specific to unmethylated DNA (e.g. \#108 in Figure 3). None of the 20 matched normal breast tissue samples showed a methylation signal (e.g. \#03 in Figure 3). Tumor samples generally exhibited also unmethylated promoter sequences due to possible contamination with small amounts of stromal and endothelial cells, as has also been described by Suzuki $e t$ al. [19]. To further confirm that SFRP2 promoter methylation in breast cancer is restricted to malignant tissue, we analyzed 17 cancer-unrelated normal breast samples. Again, none of these normal breast tissues (e.g. Figure 3) harbored detectable SFRP2 methylation.

\section{Correlation of SFRP2 promoter methylation and SFRP2 mRNA expression in breast cancer cell lines}

In order to investigate the association of SFRP2 promoter methylation with transcriptional silencing in a quantitative manner we assessed in parallel SFRP2 mRNA expression by realtime PCR and SFRP2 methylation by quantitative Pyrosequencing in breast cell lines. The technical controls for Pyrosequencing revealed median methylation of $4 \%$ (unmethylated control) and $90 \%$ (methylated control) in the 22 sequential CpG sites, by this defining the detection limits of this assay. HMEC cells exhibited abundant SFRP2 mRNA expression ( $\triangle$ cycle threshold $\left(\mathrm{C}_{\mathrm{T}}\right)$ GAPDH:SFRP2 = 5.1) (Figure 4A) together with median SFRP2 methylation of $4 \%$, in contrast to e.g. BT20 cells which exhibited mean methylation of $83 \%$ together with absence of SFRP2 mRNA expression $\left(\triangle \mathrm{C}_{\mathrm{T}}\right.$ GAPDH:SFRP2 = 19.9). Median SFRP2 methylation for Hs578T, MCF10A, MCF7, MDA-MB-231, SKBR3 and T47D was 5\%, 73\%, 73\%, 71\%, 61\% and $42 \%$, respectively. A direct comparison of SFRP2 mRNA expression and SFRP2 promoter methylation indicates that in breast cell lines SFRP2 methylation is correlated with loss of SFRP2 mRNA expression $(P<0.001$; Figure 4B). Thus, when applying an empiric cut-off of $>5 \%$ to discriminate between SFRP2 methylation and non-methylation, all semi-quantitative results for SFRP2 methylation in breast cell lines obtained by MSP could be confirmed by the quantitative Pyrosequencing assay.

\section{Differential expression of SFRP2 protein in primary breast cancer}

Immunohistochemical analysis was used to investigate SFRP2 protein expression in normal and malignant breast tissue. A total of 125 informative breast cancer cases, four DCIS and 10 normal breast tissues were analyzed. Inten- sity of immunohistochemical staining was evaluated using a semi-quantitative IRS [39]. SFRP2 protein was clearly detectable in $90 \%(9 / 10)$ of normal breast tissue samples analyzed, as defined by an IRS $\geq 8$ (Figure 5C). The mean expression was determined to be IRS $=7.5$ (range 3-8; standard deviation $(\mathrm{SD}) \pm 1.6$ ), and median expression to be IRS $=8$. Expression was predominantly localized in luminal and basal epithelial cells of the normal breast while weak expression was detectable in adjacent stromal cells. In four DCIS, SFRP2 expression was slightly reduced (mean IRS $=6.5$; range $4-8$; $\mathrm{SD} \pm 1.9$; median IRS $=7$; Figure 5D, E) with one sample showing strong reduction $(25 \%$, IRS $=4)$. However, the mean expression in invasive breast carcinomas was determined to be IRS $=4.6$ (range $0-8 ; \mathrm{SD} \pm 2.1$ ) and median expression to be IRS $=4$. Invasive breast carcinomas showed strongly reduced or complete loss (IRS $\leq 4$ ) of SFRP2 expression in $74 \%(93 / 125)$ of cases (Figure 5F, G). The SFRP2 expression difference between tumors and normal breast tissues was statistically significant $(P=0.001)$.

\section{Correlation of SFRP2 expression and SFRP2 methylation with clinicopathological parameters and patient survival} Clinicopathological characteristics of breast cancer patients were first correlated with SFRP2 protein expression for descriptive data analysis (Table 1). Loss of SFRP2 expression in tumor tissue (IRS $\leq 4$ ) was not associated with age at diagnosis, tumor size, histological grade, histological type, estrogen/progesterone receptor status, Her2 status or expression of p53. A prevalence of more abundant SFRP2 expression was detected in node negative breast tumors $(P=0.033)$. In univariate survival analysis using log-rank test, loss of SFRP2 protein expression was not associated with DFS $(P=0.237)$, but a weak trend was detected towards reduced OS $(P=0.071)$ (Figure 6). SFRP2 promoter methylation in breast carcinomas was not associated with age at diagnosis, tumor size, lymph node status, histological grade, histological type, or estrogen/progesterone receptor status (Table 2). In univariate survival analysis, lymph node status, histological grade and histological type were significantly associated with DFS; lymph node status and histological grade were significantly associated with OS (Table 3). However, SFRP2 methylation was neither associated with DFS $(P=0.192)$ nor with $\mathrm{OS}$ intervals $(P=0.686)$.

\section{SFRP2 inhibits proliferation in breast cell lines}

Finally, we asked whether SFRP2 influences proliferation rates in breast cell lines. For gain-of-function experiments we chose mammary MCF10A cells since these cells were found to lack SFRP2 mRNA expression. As shown in Figure 7A, WNT1 overexpressing MCF10A cells notably increased proliferation compared to cells mock-transfected with empty vector. The equimolar co-transfection with SFRP2resulted in a decreased proliferation rate as 

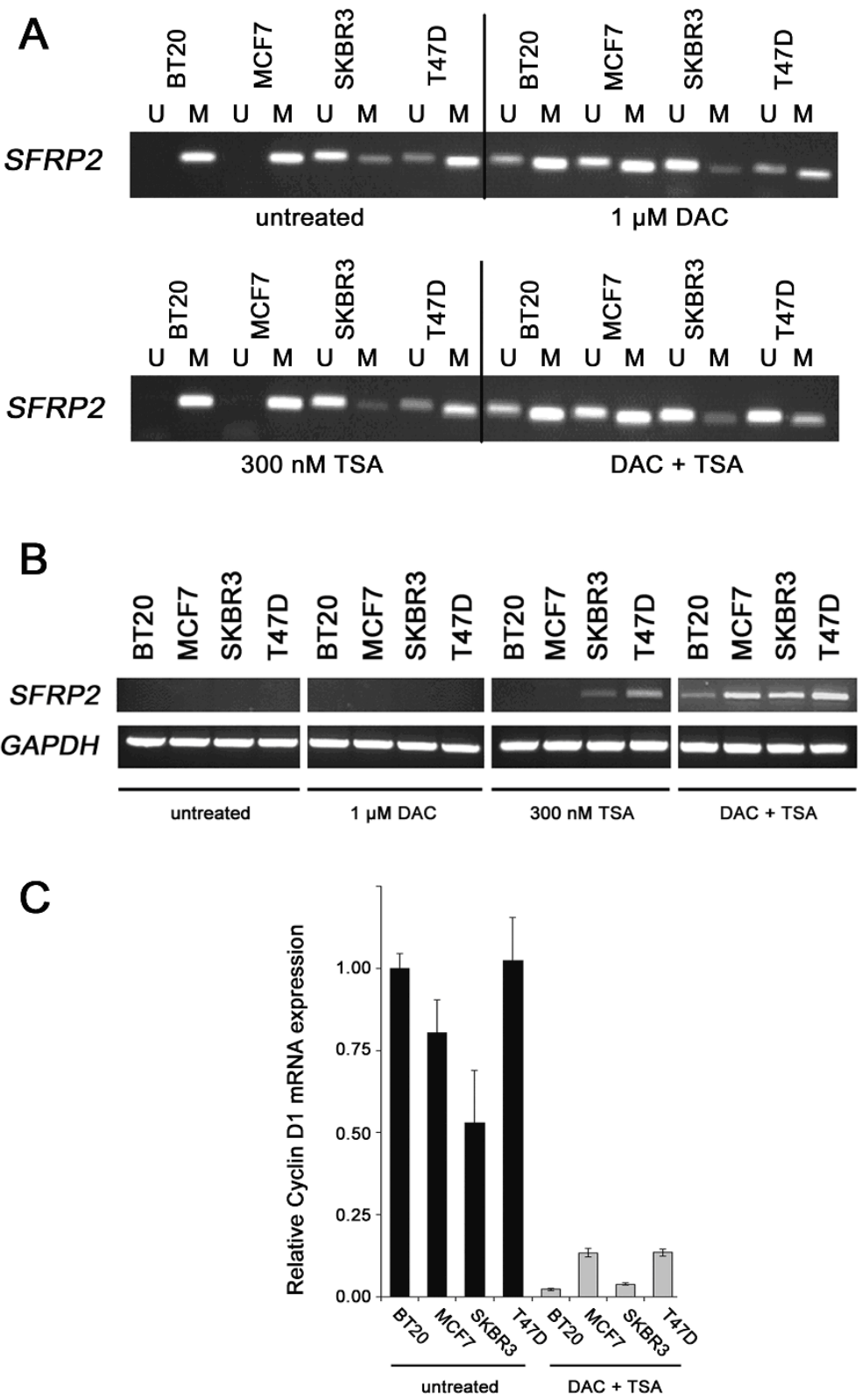

Figure 2

Global demethylation and histone acetylation restores SFRP2 expression. (A) MSP of four malignant cell lines was performed with DNA from either untreated cells, or after treatment with I $\mu$ M DAC, or after treatment with $300 \mathrm{nM}$ TSA, or after a combined treatment applying both drugs. In three cell lines (BT20, MCF7, T47D) a promoter demethylating effect could be visually detected, since signals indicative of unmethylated SFRP2 promoter arise (BT20, MCF7) or become enhanced (T47D) after the combined treatment. In T47D, DAC alone had no detectable demethylating effect on the SFRP2 promoter. (B) Expression of SFRP2 mRNA before treatment, or after treatment with I $\mu$ M DAC, or after treatment with $300 \mathrm{nM}$ TSA, or after a combined treatment applying both drugs. Treatment with DAC alone was not able to induce SFRP2 expression in all cell lines, in contrast to TSA which induced expression in two out of four cell lines (SKBR3 and T47D) previously showing partial SFRP2 methylation. However, only combined promoter demethylation and histone reacetylation leads to strong induction of SFRP2 mRNA expression in all cell lines. GAPDH served as cDNA loading control. (C) Suppression of Cyclin DI mRNA expression after global DNA demethylation of breast cancer cell lines as determined by realtime PCR. Untreated tumor cells (black bars) and cells treated with DAC/TSA (grey bars) show significantly different expression levels of Cyclin DI mRNA $(P=0.029$, two-sided Mann-Whitney U-test). Expression level of each sample is normalized to its GAPDH expression and related to untreated BT20 cells (set to I). 


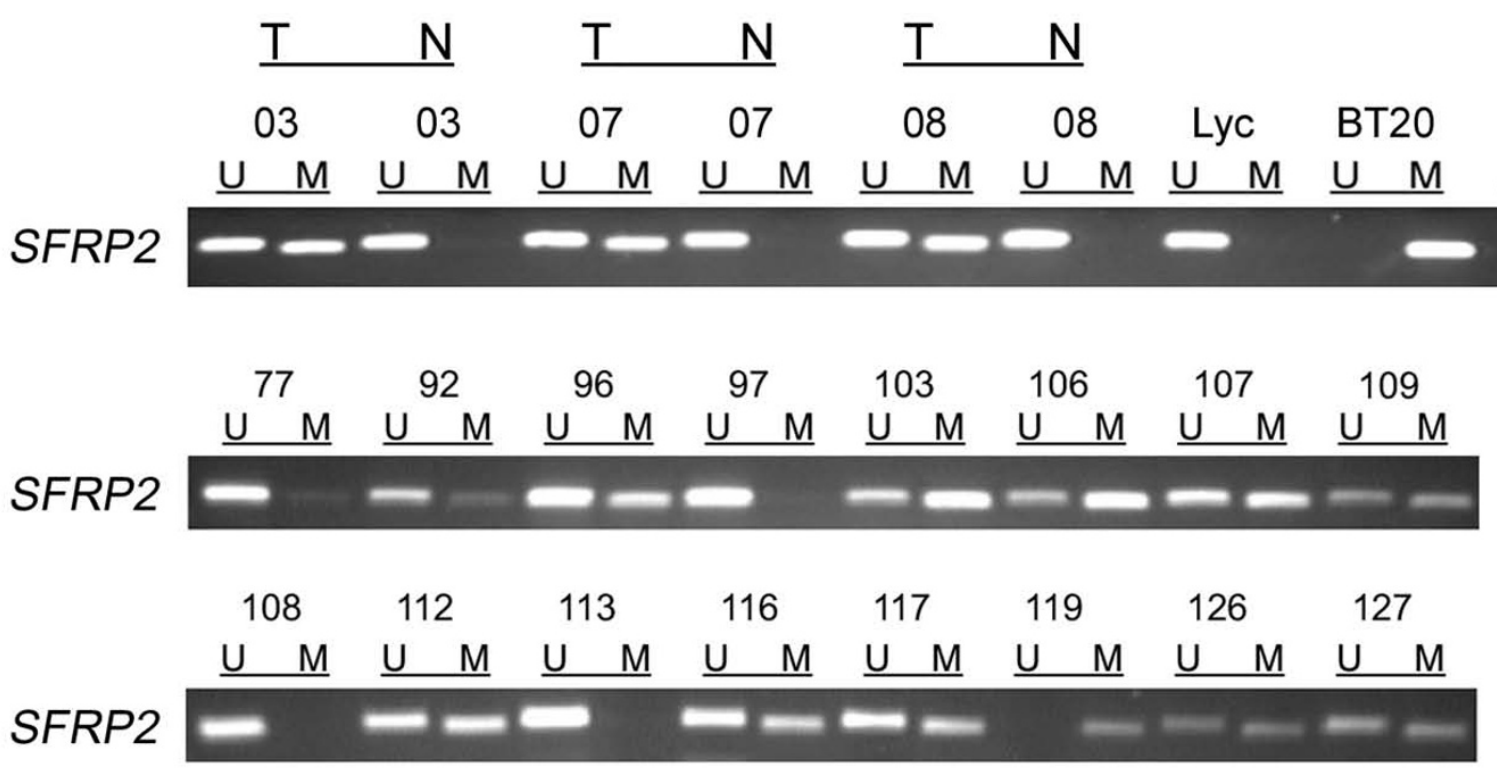

\begin{tabular}{|c|c|c|c|c|c|}
\hline & N1 & N2 & N3 & N4 & N5 \\
\hline & $\underline{U} \quad M$ & $\underline{U} \quad M$ & $\underline{U} \quad M$ & $\underline{U} \quad M$ & $\underline{\mathrm{U}} \mathrm{M}$ \\
\hline SFRP2 & - & $\longrightarrow$ & - & - & 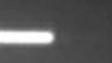 \\
\hline
\end{tabular}

Figure 3

SFRP2 methylation analysis of primary breast cancer specimens. MSP was performed on bisulfite-treated DNA from primary invasive breast cancer tissues. MSP results from 19 representative patient samples are shown. DNA bands in lanes labeled with $U$ indicate PCR products amplified with primers recognizing the unmethylated SFRP2 promoter sequence. DNA bands in lanes labeled with $M$ represent amplified products with methylation-specific primers. In addition, five representative normal cancer-unrelated breast tissues (NI - N5) are shown. DNA from the breast cancer cell line BT20 and lymphocyte DNA from a healthy donor (Lyc) served as positive controls for MSP. NTC designates the no template control; $T$ indicates tumor tissue; $\mathrm{N}$ indicates normal breast tissue.

compared to WNT1 alone. Furthermore, SFRP2-transfectants revealed a slightly reduced proliferation rate compared to cells containing empty vector. In order to support these findings we performed a colony formation assay and selected transfected clones for three weeks by the antibiotic G418. Representative results are shown in Figure 7B. Controls assured the feasibility of this assay, showing that wild type cells without G418 abundantly form colonies, whereas in the presence of G418 wild type cells fail to survive. SFRP2-transfected cells exhibit a reduced number of colonies as compared to mock-transfected cells. The difference in colony numbers from three independent experiments was statistically significant $(P=$ 0.045, two-tailed Mann-Whitney U-test).

\section{Discussion}

Aberrant methylation of $\mathrm{CpG}$ islands in gene promoters has been ascertained as a primary mechanism for the inac- tivation of tumor suppressor genes in human malignancies, including colon and breast cancer (for review see [3]). Clinically, the identification of genes that are prone to abnormal methylation and consequently become downregulated is of critical importance since this is considered to provide a good source of novel tumor biomarkers [52] and potential targets for chemotherapeutics $[53,54]$. The family of SFRP genes, functionally acting as Wnt signaling inhibitors, was recently shown to be a common target of promoter hypermethylation in numerous tumor entities [19-26]. In human breast cancer, we have previously shown that the SFRP1 and SFRP5 promoter is epigenetically silenced in $61 \%$ and $73 \%$ of invasive breast carcinomas, respectively, each of which was associated with unfavorable patient prognosis $[27,28]$. We here demonstrate that promoter methylation of SFRP2 is a further tumor-related alteration in human breast cancer occurring with even higher incidence. 
Initiating our study, we found that many breast cancer cell lines revealed abolished SFRP2 expression presumably due to methylation of the SFRP2 promoter, since those cell lines lacking SFRP2 methylation abundantly expressed SFRP2 mRNA, whereas all cell lines lacking SFRP2 expression harbored SFRP2 promoter methylation. A direct coherence between promoter methylation and loss of RNA expression was shown by a combined DAC/ TSA treatment of breast cancer cell lines, demonstrating that the SFRP2 gene was effectively demethylated and reexpressed after the treatment. Furthermore, those cell lines revealed a significant reduction of cyclin D1 expression, suggesting reactivation of anti-proliferative genes, of which SFRP2 is supposed to be a member $[19,23,24]$. Interestingly, in partially methylated SKBR3 and T47D cells the sole inhibition of histone deacetylases by TSA led to restoration of some SFRP2 expression, indicating that besides DNA methylation in these cells further reversible chromatin repressing histone modifications may exist.

Since cell lines may acquire de novo genetic and epigenetic lesions during cultivation $[55,56]$ it is mandatory to investigate such aberrations in primary tissues as well. To this end we analyzed SFRP2 promoter methylation in 199 infiltrating breast carcinomas by MSP. We found a highfrequent incidence of SFRP2 methylation in the tumors $(83 \%)$, confirming the recent results from Suzuki et al. [37], who reported of SFRP2 methylation in 60 of 78 $(77 \%)$ primary breast carcinomas. Importantly, SFRP2 methylation was independent of relevant clinicopathological factors, thus being unlikely related to disease stage
A

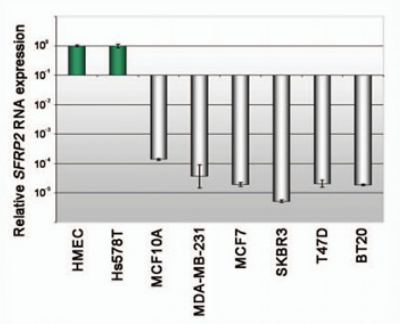

B

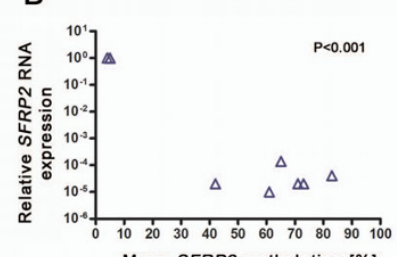

Mean SFRP2 methylation [\%]

\section{Figure 4}

Correlation of SFRP2 promoter methylation and loss of SFRP2 mRNA expression in breast cell lines. (A) Realtime PCR of eight breast cell lines revealed abundant SFRP2 mRNA expression in benign HMEC and malignant $\mathrm{Hs} 578 \mathrm{~T}$ cells (green bars), whereas in all other investigated malignant breast cell lines SFRP2 mRNA expression was substantially reduced (grey bars). (B) Plotting of SFRP2 mRNA expression from the same cell lines ( $\mathrm{Y}$-axis) against each mean SFRP2 promoter methylation value $(X$-axis) reveals a significant correlation between loss of RNA expression and SFRP2 promoter methylation ( $P=0.001$; Pearson's correlation coefficient $r=-0.924 I$ ). or a molecular breast cancer subtype. SFRP2 methylation was equally prevalent in small sized (pT1) and in larger sized (pT2-4) breast carcinomas, suggesting it occurs as early epigenetic aberration in breast tumorigenesis with no further increase in methylation frequency during tumor progression. Whether SFRP2 methylation is already present in benign and earlier premalignant lesions such as atypical hyperplasia and carcinoma in situ, like it was recently reported for the 14-3-3- $\sigma$ gene [9], will be of particular importance in regard of early breast tumor detection. Yet, this remains to be determined in a future study.

Interestingly, Suzuki et al. [37] reported that a certain number of cancer-related normal breast tissues also showed weak SFRP2 methylation in their study, whereas in our study none of the normal breast tissues harbored a methylated SFRP2 promoter, irrespective of whether the tissue was taken from matched cancer-related or unmatched cancer-unrelated specimens. Given that no contaminating tumor cells had been present in their normal breast tissues this might be due to different locations of the recruited tissues (i.e. distance to the tumor margin), and may address a phenomenon that in cancer research is currently being discussed as "field defect" $[57,58]$. Evidence of such field defect in breast cancer was brought up by Yan et al. [59] showing that RASSF1A promoter methylation in breast carcinoma may progressively diffuse outwards to surrounding normal tissue, establishing a sphere of methylation gradient around the primary tumor. Recently, such gradient was also detected for RUNX3 methylation [60], which together with RASSF1A methylation is among the earliest carcinogenetic events in breast tumor transformation. SFRP2 methylation may be implicated in such field defect in breast cancer, yet dense methylation of the SFRP2 promoter was restricted to carcinoma in our study, and thus it may display important clinical specificity. In bladder cancer, SFRP2 methylation was shown to represent an independent predictor of malignancy, although in multivariate logistic regression analysis it was not a reliable biomarker because of a limited sensitivity/specificity due to some extent of methylation in normal bladder mucosa [22]. In contrast, in faecal DNA SFRP2 methylation was proven to be a highly promising screening marker for colorectal cancer [34], even potent to detect early lesions like adenoma, aberrant crypt foci [35] and colorectal polyps [36] due to the absence of SFRP2 methylation in normal colonic mucosa. In breast cancer, the accurate specificity and sensitivity of SFRP2 methylation remains to be determined by quantitative methods in a future study, for instance by qMSP (MethyLight) [61] or the Pyrosequencing technique [62], integrating receiveroperating characteristic (ROC) curve analyses. This may potentially lead to a valuable early tumor detection marker that will ideally be assessable in patients' body fluids like blood serum, plasma or nipple aspirate. 

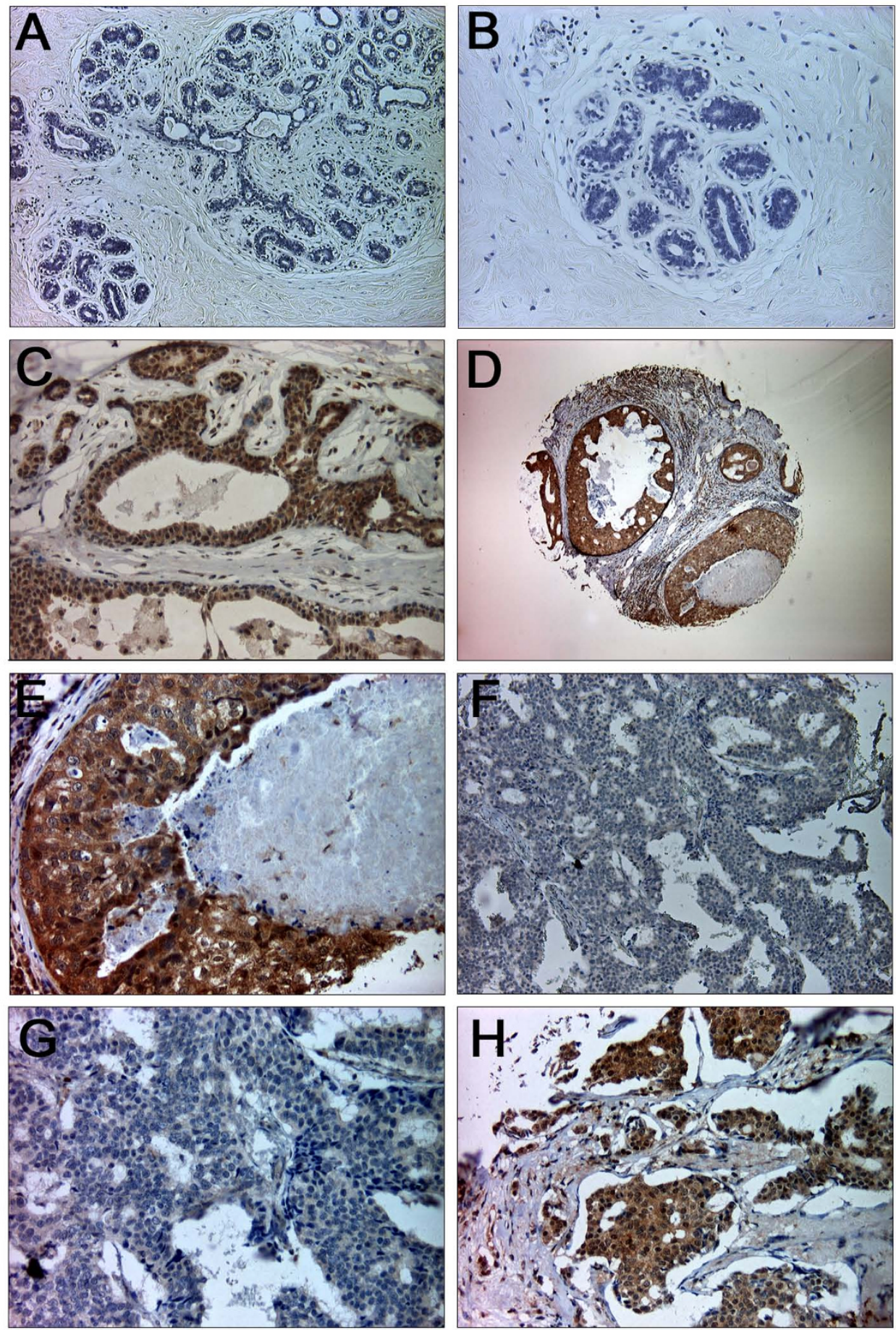

\section{Figure 5}

SFRP2 protein expression in normal and malignant breast tissues. (A) In the negative control showing normal breast tissue the primary SFRP2 antibody was omitted. (B) Scale-up of negative control shown in A. (C) Strong SFRP2 expression in ducts and lobules of normal breast tissue $(I R S=12)$. SFRP2 expression is abundant in epithelial cells, while there is only weak expression in stromal cells. (D) Very abundant SFRP2 expression in ductal carcinoma in situ of the breast. (E) Scale-up of specimen shown in D. (F) High-grade tumor exhibiting substantial loss of SFRP2 expression (IRS $=0$ ). (G) Scale-up of specimen shown in F. $(H)$ High-grade breast carcinoma with intensive cytoplasmic SFRP2 staining (IRS = I2). Original magnifications: A, F $=100 \times ; B, C, G, H=200 x ; D=40 x ; E=400 x$. 

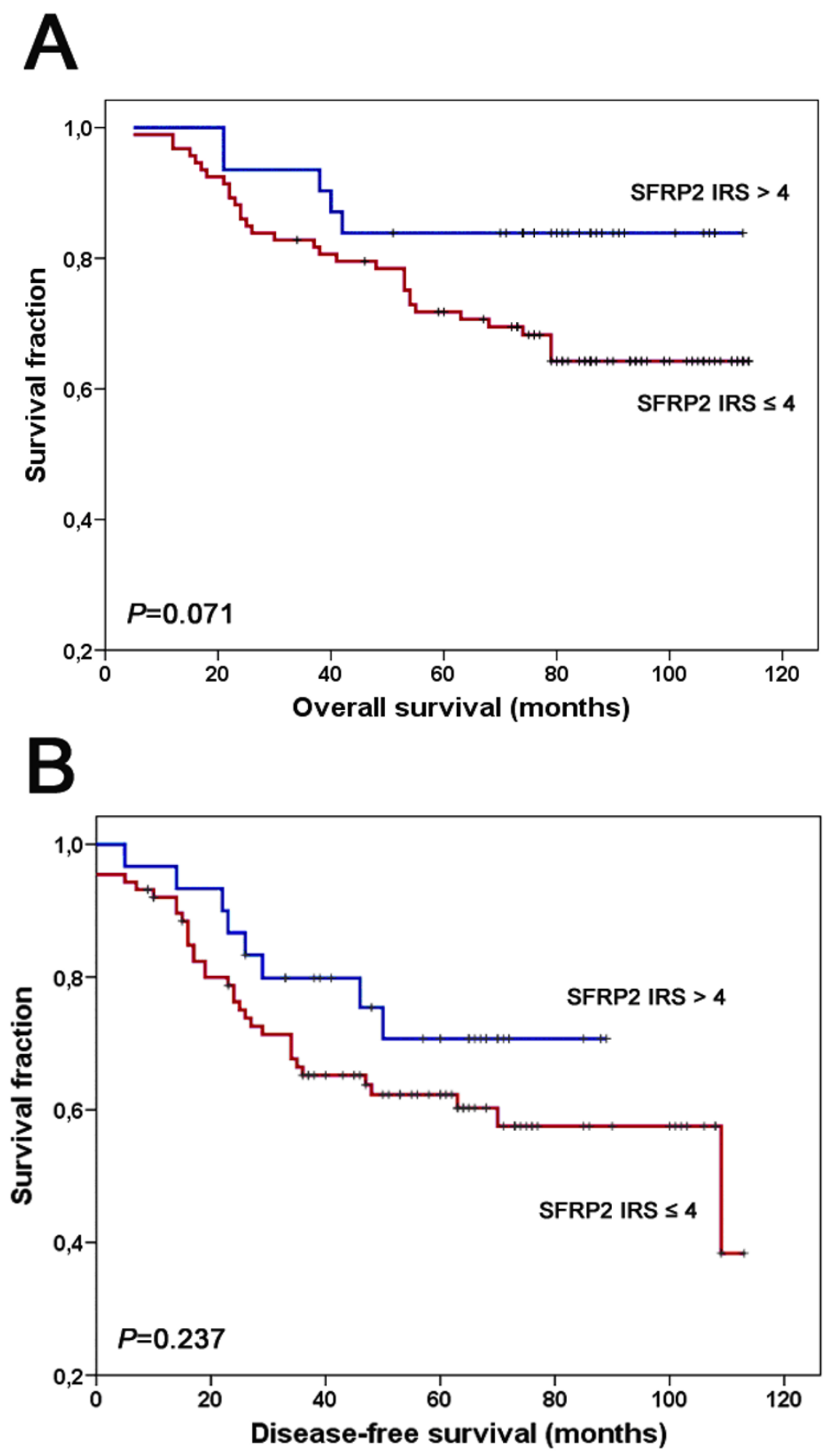

\section{Figure 6}

Loss of SFRP2 protein expression in correlation to patient survival. (A) Univariate Kaplan-Meier analysis of patient overall survival stratified between SFRP2 expresser (IRS $>4$, blue line) and SFRP2 non-expresser (IRS $\leq 4$, red line). A weak association of loss of SFRP2 protein expression with unfavorable outcome could be detected $(P=0.07 \mathrm{I}$, two-sided log-rank test). (B) Univariate Kaplan-Meier analysis regarding disease-free patient survival. The visual impression of a clinical impact of SFRP2 protein expression loss on breast tumor recurrence was statistically not significant $(P=0.237$, two-sided log-rank test). Vertical tick marks represent censored patients. 
Table I: Clinicopathological and immunohistochemical factors in relation to SFRP2 immunoreactivity

\begin{tabular}{|c|c|c|c|c|c|}
\hline \multirow[b]{2}{*}{ Variable } & \multicolumn{5}{|c|}{ SFRP2 immunoreactivity } \\
\hline & $\mathbf{n}^{\mathrm{a}}$ & IRS 0 - 4 (\%) & IRS > 4 (\%) & $\mathbf{R}^{\mathbf{d}}$ & $P$ e \\
\hline Total & 125 & $93(74)$ & $32(26)$ & & \\
\hline \multicolumn{6}{|c|}{ Clinicopathological factors } \\
\hline \multicolumn{6}{|c|}{ Age at diagnosis (median: 57 years; range $29-82$ years) } \\
\hline$<60$ years & 69 & $49(7 I)$ & $20(29)$ & -0.103 & 0.255 \\
\hline$\geq 60$ years & 55 & $44(80)$ & II (20) & & \\
\hline \multicolumn{6}{|l|}{ Tumor size ${ }^{b}$} \\
\hline pTI & 42 & $29(69)$ & $13(3 \mid)$ & -0.110 & 0.226 \\
\hline PT2 - 4 & 81 & $64(79)$ & $17(21)$ & & \\
\hline \multicolumn{6}{|l|}{ Lymph node status ${ }^{b}$} \\
\hline pNO & 62 & $41(66)$ & $21(34)$ & -0.194 & 0.033 \\
\hline $\mathrm{pNI}-3$ & 59 & $49(83)$ & $10(17)$ & & \\
\hline \multicolumn{6}{|l|}{ Histological grade } \\
\hline $\mathrm{Gl}-\mathrm{G} 2$ & 67 & $49(73)$ & $18(27)$ & -0.047 & 0.606 \\
\hline G3 & 57 & $44(77)$ & $13(23)$ & & \\
\hline \multicolumn{6}{|l|}{ Histological type } \\
\hline ductal & 98 & $73(75)$ & $25(26)$ & 0.024 & 0.796 \\
\hline lobular & 9 & $9(100)$ & $0(0)$ & & \\
\hline other & 14 & $9(64)$ & $5(36)$ & & \\
\hline \multicolumn{6}{|l|}{ Immunohistochemistry } \\
\hline \multicolumn{6}{|l|}{ Estrogen receptor status } \\
\hline negative (IRSc $0-2)$ & 28 & $20(7 I)$ & $8(29)$ & -0.079 & 0.424 \\
\hline positive (IRS $3-12$ ) & 76 & 60 (79) & $16(21)$ & & \\
\hline \multicolumn{6}{|c|}{ Progesterone receptor status } \\
\hline negative (IRSc $0-2$ ) & 72 & $55(76)$ & $17(24)$ & 0.048 & 0.611 \\
\hline positive (IRS $3-12$ ) & 43 & 31 (72) & $12(28)$ & & \\
\hline \multicolumn{6}{|l|}{ Her2 } \\
\hline negative $(0,1+)$ & 91 & $70(77)$ & $21(23)$ & 0.110 & 0.238 \\
\hline positive $(2+, 3+)$ & 26 & $17(65)$ & $9(35)$ & & \\
\hline \multicolumn{6}{|l|}{ p53 } \\
\hline negative $(<5 \%)$ & 70 & $53(76)$ & $17(24)$ & 0.033 & 0.724 \\
\hline positive $(\geq 5 \%)$ & 44 & $32(73)$ & $12(27)$ & & \\
\hline
\end{tabular}

aOnly female patients with primary, unilateral, invasive breast cancer were included. bAccording to UICC: TNM Classification of Malignant Tumours [38]. cIRS = immunoreactivity score according to Remmele and Stegner [40]. dPearson's correlation coefficient. eFisher's exact test (two-sided). Significant $P$-values are marked in bold face. Percentages may not sum to 100 due to rounding.

Contrasting the view that SFRP2 acts as a tumor suppressor gene, Lee and co-workers $[42,63]$ suggested that SFRP2 exhibits rather an oncogenic property in breast tissue since this group detected strong upregulation of SFRP2 protein in canine mammary tumors relative to normal canine breast tissues. In addition, SFRP2 overexpression in a human breast cancer cell line (MCF7) inhibited apoptosis following UV light exposure, while increasing cell-substrate adhesion capacity [64]. It is worthy to note that these experiments were carried out with a canine homologue of SFRP2 cDNA. However, five lines of evidence propose a tumor suppressive role of SFRP2 in human breast carcinogenesis: (1.) Our and another independent study [37] demonstrate that SFRP2 is very frequently tar- 
Table 2: Correlation analysis of SFRP2 promoter methylation with clinicopathological and immunohistochemical patient characteristics

\begin{tabular}{|c|c|c|c|c|c|}
\hline \multirow[b]{2}{*}{ Variable } & \multicolumn{5}{|c|}{ SFRP2 promoter } \\
\hline & $\mathbf{n}^{\mathrm{a}}$ & Unmethylated (\%) & Methylated (\%) & $\mathbf{R}^{\mathrm{b}}$ & $P c$ \\
\hline Total & 199 & $34(17)$ & $165(83)$ & & \\
\hline \multicolumn{6}{|c|}{ Clinicopathological factors } \\
\hline \multicolumn{6}{|l|}{ Age at diagnosis } \\
\hline$<60$ years & 114 & $24(2 I)$ & $90(79)$ & 0.122 & 0.091 \\
\hline$\geq 60$ years & 85 & $10(12)$ & $75(88)$ & & \\
\hline \multicolumn{6}{|l|}{ Tumor sized } \\
\hline pTI & 70 & $11(16)$ & $59(84)$ & -0.013 & 1.000 \\
\hline $\mathrm{pT} 2-4$ & 114 & $19(17)$ & $95(83)$ & & \\
\hline \multicolumn{6}{|l|}{ Lymph node status $^{d}$} \\
\hline pNo & 89 & $19(2 I)$ & $70(79)$ & 0.129 & 0.106 \\
\hline $\mathrm{pNI}-3$ & 85 & $10(12)$ & $75(88)$ & & \\
\hline \multicolumn{6}{|l|}{ Histological grade } \\
\hline $\mathrm{Gl}-\mathrm{G} 2$ & 109 & $13(12)$ & $96(88)$ & -0.139 & 0.069 \\
\hline G3 & 76 & $17(22)$ & $59(78)$ & & \\
\hline \multicolumn{6}{|l|}{ Histological type } \\
\hline ductal & 155 & $26(17)$ & $129(83)$ & -0.057 & 0.434 \\
\hline lobular & 24 & I (4) & $23(96)$ & & \\
\hline other & 14 & $5(36)$ & $9(64)$ & & \\
\hline \multicolumn{6}{|l|}{ Immunohistochemistry } \\
\hline \multicolumn{6}{|l|}{ Estrogen receptor } \\
\hline negative (IRSe $0-2$ ) & 64 & $13(20)$ & $51(80)$ & 0.084 & 0.295 \\
\hline positive (IRS $3-12$ ) & 123 & $17(14)$ & $106(86)$ & & \\
\hline \multicolumn{6}{|l|}{ Progesterone receptor } \\
\hline negative (IRSe $0-2$ ) & 70 & $14(20)$ & $56(80)$ & 0.083 & 0.304 \\
\hline positive (IRS $3-12$ ) & 117 & $16(14)$ & $101(86)$ & & \\
\hline
\end{tabular}

aOnly female patients with primary, unilateral, invasive breast cancer were included. bPearson's correlation coefficient. cFisher's exact test (twosided). dAccording to UICC: TNM Classification of Malignant Tumours [38]. eIRS = immunoreactivity score [40]. Significant $P$-values marked in bold face.

geted by promoter methylation in human breast carcinomas as compared to normal human breast tissues, disposing breast cancer to the large number of human tumor entities for which SFRP2 methylation has already been described. (2.) We found a strong correlation and functional association of SFRP2 methylation with loss of SFRP2 mRNA expression in breast cell lines. (3.) Our study reveals a common SFRP2 protein loss in human breast carcinomas with comparable frequency to promoter methylation, notably by applying the identical SFRP2-antibody that was used for the study of canine mammary tumors. (4.) We detected a weak trend towards adverse clinical patient outcome in case of SFRP2 protein expression loss. (5.) Functional analyses in human breast
[37], gastric [23,24] and colorectal cancer cell lines [19] revealed a pro-apoptotic and anti-proliferative capacity of (human) SFRP2 associated with the ability to inhibit activated Wnt signaling, altogether supporting a tumor suppressive rather than an oncogenic function of this gene. These discrepancies to canine mammary tumors may reflect subtle distinctions in the function of structurally related molecules, or alternative activities of molecules when expressed in different contexts and organisms. Furthermore, it emphasizes that study results of SFRP2 from canine breast cancer models may not be generally transferable to human breast carcinogenesis. In conclusion, SFRP2 may represent a candidate class II tumor suppressor gene whose altered expression is caused by epigenetic 
Table 3: Univariate survival analysis of clinicopathological and immunohistochemical parameters with SFRP2 promoter methylation

\begin{tabular}{|c|c|c|c|c|c|c|}
\hline \multirow[b]{2}{*}{ Variable } & \multicolumn{3}{|c|}{ Disease-free survival (DFS) } & \multicolumn{3}{|c|}{ Overall survival (OS) } \\
\hline & $\mathbf{n}^{\mathrm{a}}$ & Events & $P^{b}$ & $\mathbf{n}^{\mathrm{a}}$ & Events & $P^{b}$ \\
\hline \multicolumn{7}{|c|}{ Clinicopathological factors } \\
\hline \multicolumn{7}{|c|}{ Age at diagnosis } \\
\hline$<60$ years & 84 & 33 & 0.391 & 83 & 15 & 0.414 \\
\hline$\geq 60$ years & 52 & 18 & & 53 & 13 & \\
\hline \multicolumn{7}{|l|}{ Tumor size $^{c}$} \\
\hline PTI & 51 & 16 & 0.059 & 51 & 8 & 0.165 \\
\hline pT2 - 4 & 82 & 35 & & 82 & 20 & \\
\hline \multicolumn{7}{|c|}{ Lymph node statusc } \\
\hline pNO & 59 & 15 & 0.008 & 59 & 7 & 0.026 \\
\hline $\mathrm{pNI}-3$ & 66 & 31 & & 66 & 18 & \\
\hline \multicolumn{7}{|c|}{ Histological grade } \\
\hline $\mathrm{GI}-\mathrm{G} 2$ & 72 & 19 & 0.003 & 73 & 7 & 0.001 \\
\hline G3 & 61 & 32 & & 61 & 21 & \\
\hline \multicolumn{7}{|c|}{ Histological type } \\
\hline ductal & 109 & 35 & 0.009 & 109 & 25 & 0.622 \\
\hline lobular & 18 & 9 & & 18 & 2 & \\
\hline other & 9 & 7 & & 9 & 1 & \\
\hline
\end{tabular}

\section{Immunohistochemistry}

\begin{tabular}{|c|c|c|c|c|c|c|}
\hline \multicolumn{7}{|l|}{ Estrogen receptor } \\
\hline negative (IRS $0-2)$ & 47 & 16 & 0.644 & 46 & 12 & 0.118 \\
\hline positive (IRS 3 - I2) & 84 & 35 & & 85 & 16 & \\
\hline \multicolumn{7}{|l|}{ Progesterone receptor } \\
\hline negative $\left(\operatorname{IRS}^{d} 0-2\right)$ & 44 & 19 & 0.318 & 45 & 12 & 0.093 \\
\hline positive (IRS $3-12$ ) & 87 & 32 & & 86 & 16 & \\
\hline \multicolumn{7}{|l|}{ SFRP2 promoter } \\
\hline unmethylated & 23 & 5 & 0.192 & 23 & 5 & 0.686 \\
\hline methylated & 113 & 45 & & 113 & 23 & \\
\hline
\end{tabular}

aOnly female patients with primary, unilateral, invasive breast cancer were included. bUnivariate log-rank test (two-sided). cAccording to UICC:

TNM Classification of Malignant Tumours [38]. dIRS = immunoreactivity score [40]. Significant $P$-values marked in bold face.

changes (class II) rather than by mutation (class I) [65]. Class II tumor suppressor genes are particularly interesting drug targets since reversing the block of their gene expression, e.g. by DNA methyltransferase (DNMT) inhibitors or histone deacetylase (HDAC) inhibitors could lead to tumor regression. Furthermore such a treatment could be appropriate to eliminate minimal residual cancer disease after surgical resection of the tumor.

Summarizing, our data demonstrate that SFRP2 is a frequent target of epigenetic inactivation in human breast cancer leading to downregulation of SFRP2 expression in mammary tumors. Loss of SFRP2 expression confers a growth advantage to mammary cells, likely due its ability to inhibit oncogenic Wnt signaling. Altogether, our data support the proposed tumor suppressive function of SFRP2 in normal breast tissue. The high incidence and the putative specificity of this epimutation may qualify SFRP2 methylation as potential candidate in a screening marker panel for the early detection of human breast cancer.

\section{Conclusion}

Our study on SFRP2 in human breast cancer leads to the following conclusions: SFRP2 expression is very fre- 


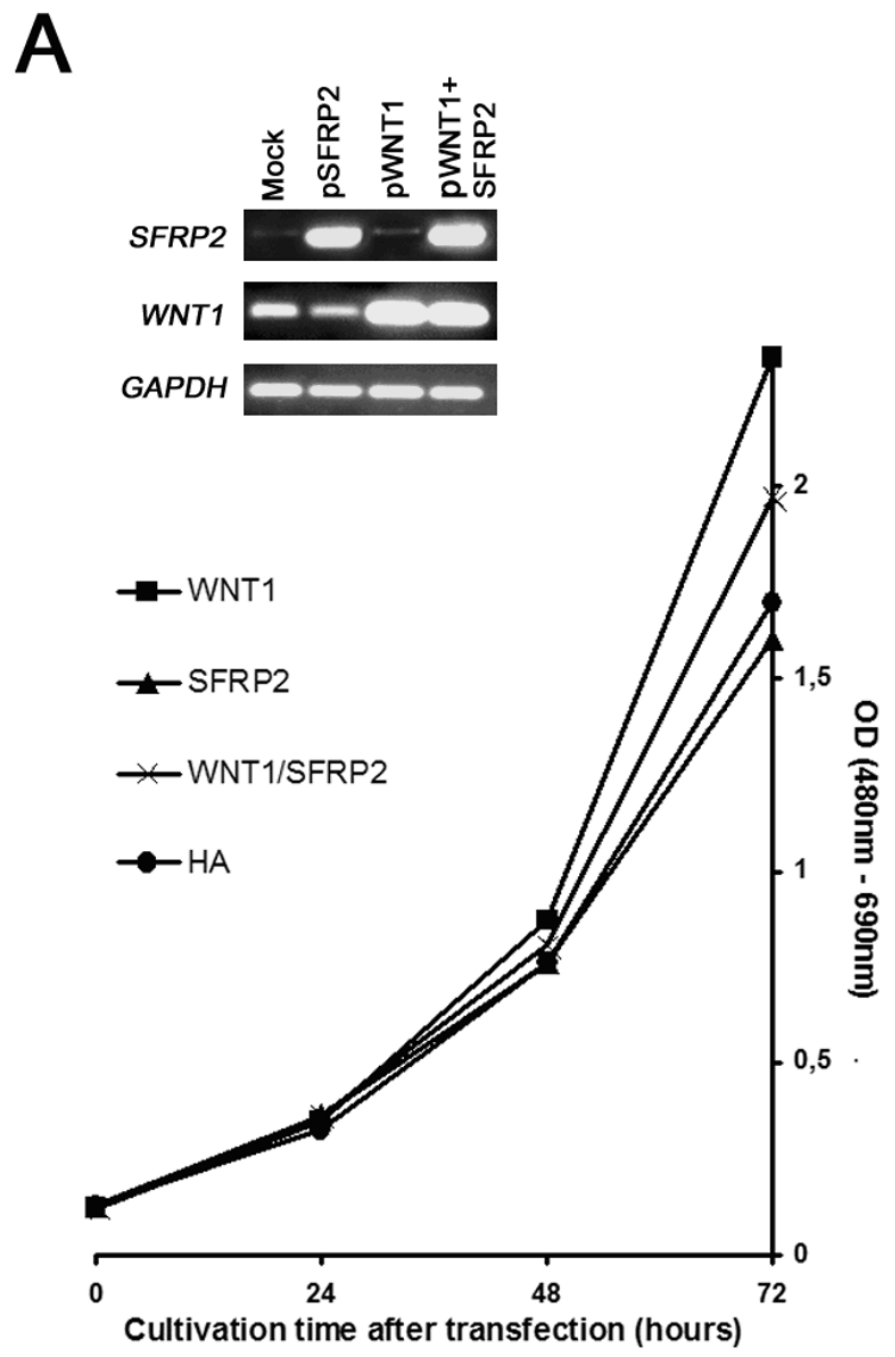

B
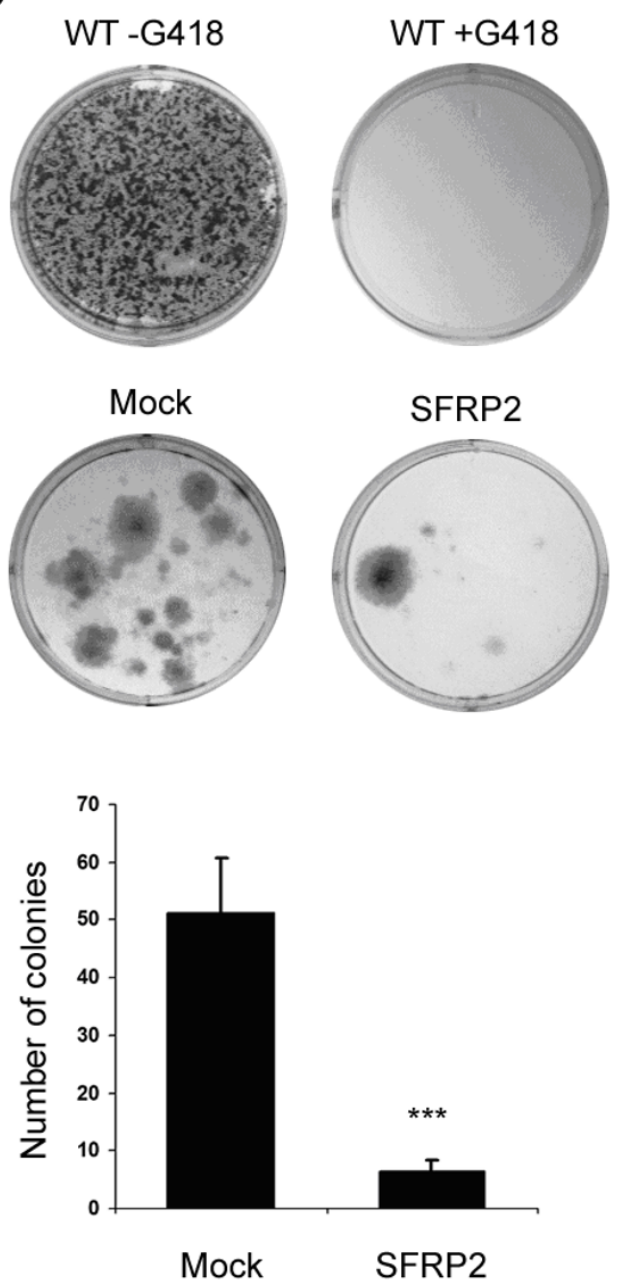

\section{Figure 7}

SFRP2 inhibits proliferation in breast epithelial cells. (A) MCFIOA cells transfected with empty vector (Mock), SFRP2expression vector, WNTI-expression vector or a combination of SFRP2+WNTI-expression vectors were subjected to XTT proliferation assays. At three subsequent time points, optical densities (OD) of the supernatants were measured. RNA Expression of the respective genes was surveyed in parallel 4 days post transfection. GAPDH served as CDNA loading control. SFRP2 was able to reduce a proliferative effect mediated by WNTI overexpression, whereas the inhibiting effect of SFRP2 on cells not stimulated by WNTI was only marginal (HA). (B) Long-term inhibiting effects of SFRP2 on the ability to form colonies in MCFIOA cells. Cells were either transfected with empty vector (Mock) or with SFRP2-expression vector, and after 3 weeks of selective pressure (antibiotic G418) fixed, stained and photographed. Non-transfected wild type cells (WT) are shown as controls with (+) and without (-) the application of G4I8. The difference in colony numbers between mock-transfected and SFRP2transfected cells is significant $(P=0.045$; two-tailed Mann-Whitney $U$-test $)$.

quently downregulated in breast cancer due to promoter methylation, thus conferring growth advantage to neoplastic mammary cells. Therefore, SFRP2 may be assigned a class II tumor suppressor gene in normal breast tissue, whose block of expression could be reversed by DNA demethylating (DNMT inhibitors) and histone reacetylating (HDAC inhibitors) drugs. In contrast to an adverse prognostic value of SFRP1 or SFRP5 methylation in breast cancer, failure of SFRP2 methylation as a prognostic biomarker may be explained by redundant functions of these closely related SFRP molecules. Alternatively, this failure could be explained by the likely involvement of SFRP2 methylation in the early steps of breast carcinogenesis, rather than being implicated in the development of 
prognostically adverse tumor subtypes. Nevertheless, SFRP2 methylation may be potentially useful as a molecular tumor biomarker in a DNA methylation biomarker based screening assay, as it may display high clinical sensitivity and specificity in detecting breast cancer cells.

\section{Competing interests}

The authors declare that they have no competing interests.

\section{Authors' contributions}

JV participated in the design of the study, carried out the RNA expression and methylation analyses, immunohistochemical studies, in vitro experiments, statistical analysis, and wrote the manuscript. EN performed realtime expression analysis, assisted in Pyrosequencing and data interpretation, and critically revised the manuscript. NB participated in immunohistochemical analysis and data interpretation, and critically revised the manuscript. EJ designed and optimized the SFRP2 Pyrosequencing assay, and critically revised the manuscript. AH participated in collection of clinical data, performed data interpretation, and critically revised the manuscript. RK participated in the design and coordination of the study, and critically revised the manuscript. ED planned and coordinated the study, and critically revised the manuscript. All authors have read and approved the final version of the manuscript.

\section{Additional material}

\section{Additional file 1}

Clinicopathological and immunohistochemical characteristics of primary invasive breast carcinomas $(n=199)$. The data provided represent the relevant clinicopathological and immunohistochemical patient characteristics used in SFRP2 methylation analysis.

Click here for file

[http://www.biomedcentral.com/content/supplementary/14764598-7-83-S1.doc]

\section{Additional file 2}

Primer sequences and cycle conditions used in this study. This table provides oligonucleotide primer sequences and PCR cycle conditions that were used throughout this study.

Click here for file

[http://www.biomedcentral.com/content/supplementary/14764598-7-83-S2.doc]

\section{Acknowledgements}

The expert technical help of Sevim Alkaya, Sonja von Serényi and Inge Losen is greatly appreciated. We thank Dr. Dieter Niederacher (Department of Gynecology and Obstetrics, Heinrich-Heine-University, Düsseldorf, Germany) and Prof. Matthias Dürst (Friedrich-Schiller University, Jena, Germany) for kindly providing patient samples. We are thankful to Dr. Monika Klinkhammer-Schalke and Monika Kerscher from the Tumor Registry Regensburg for continuous help in obtaining clinical follow-up data. The SFRP2/WNTI vectors were a kind gift from Dr. Hiromu Suzuki (Sap- poro Medical University, Sapporo, Japan). This work is a research project within the German Human Genome Project and has been supported by the grant from the Bundesministerium für Bildung und Forschung to Edgar Dahl (0IKW040I).

\section{References}

I. Herman JG, Baylin S: Gene silencing in cancer in association with promoter hypermethylation. N Engl J Med 2003, 349:2042-2054

2. Esteller M: Aberrant DNA methylation as a cancer-inducing mechanism. Annu Rev Pharmacol Toxicol 2005, 45:629-656.

3. Agrawal A, Murphy RF, Agrawal DK: DNA methylation in breast and colorectal cancers. Mod Pathol 2007, 20:71 I-72I.

4. Herman JG, Merlo A, Mao L, Lapidus RG, Issa JP, Davidson NE, Sidransky D, Baylin SB: Inactivation of the CDKN2/p I 6/MTS I gene is frequently associated with aberrant DNA methylation in all common human cancers. Cancer Res 1995, 55:4525-4530.

5. Ottaviano YL, Issa JP, Parl FF, Smith HS, Baylin SB, Davidson NE: Methylation of the estrogen receptor gene $C p G$ island marks loss of estrogen receptor expression in human breast cancer cells. Cancer Res 1994, 54:2552-2555.

6. Graff JR, Herman JG, Lapidus RG, Chopra H, Xu R, Jarrard DF, Isaacs WB, Pitha PM, Davidson NE, Baylin SB: E-cadherin expression is silenced by DNA hypermethylation in human breast and prostate carcinomas. Cancer Res 1995, 55:5195-5199.

7. Lehmann U, Celikkaya G, Hasemeier B, Länger F, Kreipe H: Promoter hypermethylation of the death-associated protein kinase gene in breast cancer is associated with the invasive lobular subtype. Cancer Res 2002, 62:6634-6638.

8. Veeck J, Chorovicer M, Naami A, Breuer E, Zafrakas M, Bektas N, Dürst M, Kristiansen G, Wild PJ, Hartmann A, Knuechel R, Dahl E: The extracellular matrix protein ITIH5 is a novel prognostic marker in invasive node-negative breast cancer and its aberrant expression is caused by promoter hypermethylation. Oncogene 2008, 27:865-875.

9. Umbricht CB, Evron E, Gabrielson E, Ferguson A, Marks J, Sukumar $S$ : Hypermethylation of 14-3-3 sigma (stratifin) is an early event in breast cancer. Oncogene 200 I, 20:3348-3353.

10. Belinsky SA, Liechty KC, Gentry FD, Wolf HJ, Rogers J, Vu K, Haney J, Kennedy TC, Hirsch FR, Miller Y, Franklin WA, Herman JG, Baylin SB, Bunn PA, Byers T: Promoter hypermethylation of multiple genes in sputum precedes lung cancer incidence in a highrisk cohort. Cancer Res 2006, 66:3338-3344.

II. Jones SE, Jomary C: Secreted Frizzled-related proteins: searching for relationships and patterns. Bioessays 2002, 24:8I I-820.

12. Uren A, Reichsman F, Anest V, Taylor WG, Muraiso K, Bottaro DP, Cumberledge S, Rubin JS: Secreted frizzled-related protein-I binds directly to Wingless and is a biphasic modulator of Wnt signaling. J Biol Chem 2000, 275:4374-4382.

13. Bafico A, Liu G, Yaniv A, Gazit A, Aaronson SA: Novel mechanism of Wnt signalling inhibition mediated by Dickkopf-I interaction with LRP6/Arrow. Nat Cell Biol 200I, 3:683-686.

14. Polakis P: Wnt signaling and cancer. Genes Dev 2000, I 4: |837-|85I.

I5. Bukholm IK, Nesland JM, Børresen-Dale AL: Re-expression of Ecadherin, alpha-catenin and beta-catenin, but not of gammacatenin, in metastatic tissue from breast cancer patients. J Pathol 2000, 190:15-19.

16. Ryo A, Nakamura M, Wulf G, Liou YC, Lu KP: Pin I regulates turnover and subcellular localization of beta-catenin by inhibiting its interaction with APC. Nat Cell Biol 200I, 3:793-80I.

17. Lin SY, Xia W, Wang JC, Kwong KY, Spohn B, Wen Y, Pestell RG, Hung MC: Beta-catenin, a novel prognostic marker for breast cancer: its roles in cyclin DI expression and cancer progression. Proc Natl Acad Sci USA 2000, 97:4262-4266.

18. Chung GG, Zerkowski MP, Ocal IT, Dolled-Filhart M, Kang JY, Psyrri A, Camp RL, Rimm DL: beta-Catenin and p53 analyses of a breast carcinoma tissue microarray. Cancer 2004, I 00:2084-2092.

19. Suzuki H, Watkins DN, Jair KW, Schuebel KE, Markowitz SD, Chen WD, Pretlow TP, Yang B, Akiyama $Y$, van Engeland $M$, Toyota $M$, Tokino T, Hinoda Y, Imai K, Herman JG, Baylin SB: Epigenetic inactivation of SFRP genes allows constitutive WNT signaling in colorectal cancer. Nat Genet 2004, 36:417-422. 
20. Lee AY, He B, You L, Dadfarmay S, Xu Z, Mazieres J, Mikami I, McCormick F, Jablons DM: Expression of the secreted frizzledrelated protein gene family is downregulated in human mesothelioma. Oncogene 2004, 23:6672-6676.

21. Urakami S, Shiina H, Enokida H, Hirata H, Kawamoto K, Kawakami T, Kikuno N, Tanaka Y, Majid S, Nakagawa M, Igawa M, Dahiya R: Wnt antagonist family genes as biomarkers for diagnosis, staging, and prognosis of renal cell carcinoma using tumor and serum DNA. Clin Cancer Res 2006, I 2:6989-6997.

22. Urakami S, Shiina $\mathrm{H}$, Enokida $\mathrm{H}$, Kawakami T, Kawamoto K, Hirata $\mathrm{H}$, Tanaka Y, Kikuno N, Nakagawa M, Igawa M, Dahiya R: Combination analysis of hypermethylated Wnt-antagonist family genes as a novel epigenetic biomarker panel for bladder cancer detection. Clin Cancer Res 2006, 12:2109-2116.

23. Cheng YY, Yu J, Wong YP, Man EP, To KF, Jin VX, Li J, Tao Q, Sung JJ, Chan FK, Leung WK: Frequent epigenetic inactivation of secreted frizzled-related protein 2 (SFRP2) by promoter methylation in human gastric cancer. Br J Cancer 2007, 97:895-90I.

24. Nojima M, Suzuki H, Toyota M, Watanabe $Y$, Maruyama R, Sasaki S, Sasaki Y, Mita H, Nishikawa N, Yamaguchi K, Hirata K, Itoh F, Tokino T, Mori M, Imai K, Shinomura Y: Frequent epigenetic inactivation of SFRP genes and constitutive activation of Wnt signaling in gastric cancer. Oncogene 2007, 26:4699-47।3.

25. Nomoto S, Kinoshita T, Kato K, Otani S, Kasuya H, Takeda S, Kanazumi N, Sugimoto $\mathrm{H}$, Nakao A: Hypermethylation of multiple genes as clonal markers in multicentric hepatocellular carcinoma. Br J Cancer 2007, 97:1260-1265.

26. Dahl E, Wiesmann F, Woenckhaus M, Stoehr R, Wild PJ, Veeck J, Knüchel R, Klopocki E, Sauter G, Simon R, Wieland WF, Walter B, Denzinger S, Hartmann A, Hammerschmied CG: Frequent loss of SFRP I expression in multiple human solid tumours: association with aberrant promoter methylation in renal cell carcinoma. Oncogene 2007, 26:5680-569l.

27. Veeck J, Niederacher D, An H, Klopocki E, Wiesmann F, Betz B, Galm O, Camara O, Dürst M, Kristiansen G, Huszka C, Knüchel R, Dahl E: Aberrant methylation of the Wnt antagonist SFRPI in breast cancer is associated with unfavourable prognosis. Oncogene 2006, 25:3479-3488.

28. Veeck J, Geisler C, Noetzel E, Alkaya S, Hartmann A, Knüchel R, Dahl E: Epigenetic inactivation of the Secreted frizzled-related protein-5 (SFRP5) gene in human breast cancer is associated with unfavorable prognosis. Carcinogenesis 2008, 29:99I-998.

29. Suzuki H, Gabrielson E, Chen W, Anbazhagan R, van Engeland M, Weijenberg MP, Herman JG, Baylin SB: A genomic screen for genes upregulated by demethylation and histone deacetylase inhibition in human colorectal cancer. Nat Genet 2002, 3I:I4I-I49.

30. Zou H, Molina JR, Harrington JJ, Osborn NK, Klatt KK, Romero Y, Burgart LJ, Ahlquist DA: Aberrant methylation of secreted frizzled-related protein genes in esophageal adenocarcinoma and Barrett's esophagus. Int J Cancer 2005, I I 6:584-59I.

31. Marsit C), Karagas MR, Andrew A, Liu M, Danaee H, Schned AR, Nelson HH, Kelsey KT: Epigenetic inactivation of SFRP genes and TP53 alteration act jointly as markers of invasive bladder cancer. Cancer Res 2005, 65:708I-7085.

32. Fukui T, Kondo M, Ito G, Maeda O, Sato N, Yoshioka H, Yokoi K, Ueda Y, Shimokata K, Sekido Y: Transcriptional silencing of secreted frizzled related protein I (SFRPI) by promoter hypermethylation in non-small-cell lung cancer. Oncogene 2005, 24:6323-6327.

33. Qi J, Zhu YQ, Luo J, Tao WH: Hypermethylation and expression regulation of secreted frizzled-related protein genes in colorectal tumor. World ] Gastroenterol 2006, I 2:7 | I 3-7 I I 7.

34. Müller HM, Oberwalder M, Fiegl H, Morandell M, Goebel G, Zitt M, Mühlthaler M, Ofner D, Margreiter R, Widschwendter M: Methylation changes in faecal DNA: a marker for colorectal cancer screening? Lancet 2004, 363: I 283-1 285.

35. Huang ZH, Li LH, Yang F, Wang JF: Detection of aberrant methylation in fecal DNA as a molecular screening tool for colorectal cancer and precancerous lesions. World J Gastroenterol 2007, 13:950-954.

36. Oberwalder M, Zitt M, Wöntner C, Fiegl H, Goebel G, Zitt M, Köhle O, Mühlmann G, Ofner D, Margreiter R, Müller HM: SFRP2 methylation in fecal DNA-a marker for colorectal polyps. Int J Colorectal Dis 2008, 23:15-19.
37. Suzuki H, Toyota M, Caraway H, Gabrielson E, Ohmura T, Fujikane T, Nishikawa N, Sogabe Y, Nojima M, Sonoda T, Mori M, Hirata K, Imai K, Shinomura $Y$, Baylin SB, Tokino T: Frequent epigenetic inactivation of $\mathrm{Wnt}$ antagonist genes in breast cancer. $\mathrm{Br}$ Cancer 2008, 98: I| $47-1 \mid 56$.

38. Sobin LH, Wittekind C, eds: UICC: TNM classification of malignant tumors. 5th edition. New York: Wiley-Liss; 1997.

39. Elston EW, Ellis IO: Method for grading breast cancer. J Clin Pathol 1993, 46: 189-190.

40. Remmele W, Stegner HE: Recommendation for uniform definition of an immunoreactive score (IRS) for immunohistochemical estrogen receptor detection (ER-ICA) in breast cancer tissue. Pathologe 1987, 8:138-40.

4I. Dahl E, Kristiansen G, Gottlob K, Klaman I, Ebner E, Hinzmann B, Hermann K, Pilarsky C, Dürst M, Klinkhammer-Schalke M, Blaszyk H, Knuechel R, Hartmann A, Rosenthal A, Wild PJ: Molecular profiling of laser-microdissected matched tumor and normal breast tissue identifies karyopherin alpha2 as a potential novel prognostic marker in breast cancer. Clin Cancer Res 2006, 1 2:3950-3960.

42. Lee JL, Chang CJ, Wu SY, Sargan DR, Lin CT: Secreted frizzledrelated protein 2 (SFRP2) is highly expressed in canine mammary gland tumors but not in normal mammary glands. Breast Cancer Res Treat 2004, 84:। 39-149.

43. Herman JG, Graff JR, Myohanen S, Nelkin BD, Baylin SB: Methylation-specific PCR: a novel PCR assay for methylation status of CpG islands. Proc Natl Acad Sci USA 1996, 93:982I-9826.

44. Galm O, Herman JG: Methylation-specific polymerase chain reaction. Methods Mol Med 2005, I I 3:279-29I.

45. Liu TH, Raval A, Chen SS, Matkovic JJ, Byrd JC, Plass C: CpG island methylation and expression of the secreted frizzled-related protein gene family in chronic lymphocytic leukemia. Cancer Res 2006, 66:653-658.

46. CpG Island Searcher [http://cpgislands.usc.edu/]

47. Ensembl Genome Browser [http://www.ensembl.org/ index.html]

48. Takai D, Jones PA: Comprehensive analysis of CpG islands in human chromosomes 21 and 22. Proc Natl Acad Sci USA 2002, 99:3740-3745.

49. Li LC, Dahiya R: MethPrimer: designing primers for methylation PCRs. Bioinformatics 2002, 18: | $427-|43|$

50. Tetsu $\mathrm{O}$, McCormick $\mathrm{F}$ : Beta-catenin regulates expression of cyclin DI in colon carcinoma cells. Nature 1999, 398:422-426.

5I. Bartkova J, Lukas J, Müller H, Lützhøft D, Strauss M, Bartek J: Cyclin DI protein expression and function in human breast cancer. Int J Cancer 1994, 57:353-36I.

52. Laird PW: The power and the promise of DNA methylation markers. Nat Rev Cancer 2003, 3:253-266.

53. Issa JP, Garcia-Manero G, Giles FJ, Mannari R, Thomas D, Faderl S, Bayar E, Lyons J, Rosenfeld CS, Cortes J, Kantarjian HM: Phase I study of low-dose prolonged exposure schedules of the hypomethylating agent 5-aza-2'-deoxycytidine (decitabine) in hematopoietic malignancies. Blood 2004, 103:1635-1640.

54. Egger G, Liang G, Aparicio A, Jones PA: Epigenetics in human disease and prospects for epigenetic therapy. Nature 2004, 429:457-463.

55. Osborne CK, Hobbs K, Trent JM: Biological differences among MCF-7 human breast cancer cell lines from different laboratories. Breast Cancer Res Treat 1987, 9:| | I-|2|

56. Wistuba II, Behrens C, Milchgrub S, Syed S, Ahmadian M, Virmani AK, Kurvari V, Cunningham TH, Ashfaq R, Minna JD, Gazdar AF: Comparison of features of human breast cancer cell lines and their corresponding tumors. Clin Cancer Res 1998, 4:293I-2938.

57. Shen L, Kondo Y, Rosner GL, Xiao L, Hernandez NS, Vilaythong J, Houlihan PS, Krouse RS, Prasad AR, Einspahr JG, Buckmeier J, Alberts DS, Hamilton SR, Issa JP: MGMT promoter methylation and field defect in sporadic colorectal cancer. I Natl Cancer Inst 2005, 97:1330-1338.

58. Maekita T, Nakazawa K, Mihara M, Nakajima T, Yanaoka K, Iguchi M, Arii K, Kaneda A, Tsukamoto T, Tatematsu M, Tamura G, Saito D, Sugimura T, Ichinose M, Ushijima T: High levels of aberrant DNA methylation in Helicobacter pylori-infected gastric mucosae and its possible association with gastric cancer risk. Clin Cancer Res 2006, I 2:989-995.

59. Yan PS, Venkataramu C, Ibrahim A, Liu JC, Shen RZ, Diaz NM, Centeno B, Weber F, Leu YW, Shapiro CL, Eng C, Yeatman TJ, Huang TH: 
Mapping geographic zones of cancer risk with epigenetic biomarkers in normal breast tissue. Clin Cancer Res 2006, 1 2:6626-6636.

60. Cheng AS, Culhane AC, Chan MW, Venkataramu CR, Ehrich M, Nasir A, Rodriguez BA, Liu J, Yan PS, Quackenbush J, Nephew KP, Yeatman TJ, Huang TH: Epithelial progeny of estrogen-exposed breast progenitor cells display a cancer-like methylome. Cancer Res 2008, 68: $1786-1796$.

61. Trinh BN, Long TI, Laird PW: DNA methylation analysis by MethyLight technology. Methods 200I, 25:456-462.

62. Colella S, Shen L, Baggerly KA, Issa PJ, Krahe R: Sensitive and quantitative universal Pyrosequencing methylation analysis of CpG sites. Biotechniques 2003, 35:146-150.

63. Lee JL, Chang C), Chueh LL, Lin CT: Secreted Frizzled Related Protein 2 (sFRP2) Decreases Susceptibility to UV-Induced Apoptosis in Primary Culture of Canine Mammary Gland Tumors by NF-kappaB Activation or JNK Suppression. Breast Cancer Res Treat 2006, 100:49-58.

64. Lee JL, Lin CT, Chueh LL, Chang CJ: Autocrine/paracrine secreted Frizzled-related protein 2 induces cellular resistance to apoptosis: a possible mechanism of mammary tumorigenesis. J Biol Chem 2004, 279: I 4602-I 4609.

65. Sager R: Tumor suppressor genes: the puzzle and the promise. Science 1989, 246:1406-14|2.

Publish with Bio Med Central and every scientist can read your work free of charge

"BioMed Central will be the most significant development for disseminating the results of biomedical research in our lifetime. "

Sir Paul Nurse, Cancer Research UK

Your research papers will be:

- available free of charge to the entire biomedical community

- peer reviewed and published immediately upon acceptance

- cited in PubMed and archived on PubMed Central

- yours - you keep the copyright 